\title{
Overview of transient liquid phase and partial transient liquid phase bonding
}

\author{
Grant O. Cook III · Carl D. Sorensen
}

Received: 19 January 2011/Accepted: 12 April 2011/Published online: 7 May 2011

(C) Springer Science+Business Media, LLC 2011

\begin{abstract}
Transient liquid phase (TLP) bonding is a relatively new bonding process that joins materials using an interlayer. On heating, the interlayer melts and the interlayer element (or a constituent of an alloy interlayer) diffuses into the substrate materials, causing isothermal solidification. The result of this process is a bond that has a higher melting point than the bonding temperature. This bonding process has found many applications, most notably the joining and repair of Ni-based superalloy components. This article reviews important aspects of TLP bonding, such as kinetics of the process, experimental details (bonding time, interlayer thickness and format, and optimal bonding temperature), and advantages and disadvantages of the process. A wide range of materials that TLP bonding has been applied to is also presented. Partial transient liquid phase (PTLP) bonding is a variant of TLP bonding that is typically used to join ceramics. PTLP bonding requires an interlayer composed of multiple layers; the most common bond setup consists of a thick refractory core sandwiched by thin, lower-melting layers on each side. This article explains how the experimental details and bonding kinetics of PTLP bonding differ from TLP bonding. Also, a range of materials that have been joined by PTLP bonding is presented.
\end{abstract}

\section{Transient liquid phase (TLP) bonding}

Transient liquid phase (TLP) bonding is a joining process that was developed to improve upon existing bonding

G. O. Cook III $(\bowtie) \cdot$ C. D. Sorensen

Ira A. Fulton College of Engineering and Technology, Brigham

Young University, 435 CTB, Provo, UT 84604, USA

e-mail: goc3.engineer@mac.com technologies. Specifically, this process was patented by Paulonis et al. in 1971 [1] to overcome deficiencies of then current bonding techniques in joining Ni-based superalloys [2-6]. TLP bonding's main advantage is that resulting bonds have a higher melting point than the bonding temperature. This bonding process characteristically lies between diffusion bonding and brazing - for this reason, it is commonly called diffusion brazing. The process is also referred to by names such as transient insert liquid metal bonding [7] and is sometimes mistakenly referred to as diffusion bonding (which by definition relies solely on solid-state diffusion). See reference [8] for a detailed history of TLP bonding and its many names.

TLP bonding process

The TLP bonding process involves the following steps:

- setting up the bond

- heating to the specified bonding temperature to produce a liquid in the bond region

- holding the assembly at the bonding temperature until the liquid has isothermally solidified due to diffusion

- homogenizing the bond at a suitable heat-treating temperature.

Bond setup usually consists of placing a thin interlayer between the substrates, but the interlayer material is occasionally placed outside the joint to flow in by capillarity $[6,7,9-15]$ as is done in many brazing processes. The interlayer material can be in many different formats:

- thin foil (rolled sheet) $[2-4,7,16-62]$

- amorphous foil (melt-spun) [7, 58-84]

- fine powders (with or without binding agent) $[5,7,15$ 17, 85-98] 
Table 1 Fixturing pressures used during TLP bonding

\begin{tabular}{lcl}
\hline Nearest order & Freq. $(\%)$ & References \\
\hline $1 \mathrm{kPa}$ & 8 & {$[89,93,98,114-116]$} \\
$10 \mathrm{kPa}$ & 5 & {$[66,117-119]$} \\
$100 \mathrm{kPa}$ & 16 & {$[23-25,33,61,68,72,88,90,99,113,120]$} \\
$1 \mathrm{MPa}$ & 36 & {$[3,21,22,26,27,29-31,34,65,69-71,73,97,102,103,121-128]$} \\
$10 \mathrm{MPa}$ & 31 & {$[17,28,32,35,59,60,62-64,67,74,94-96,100,110,111,129-133]$} \\
$100 \mathrm{MPa}$ & 4 & {$[110,112,134]$} \\
\hline
\end{tabular}

- powder compact (made by sintering, cold isostatic pressing, etc.) [57, 99-101]

- brazing paste [9, 17, 102-104]

- a physical vapor deposition process such as sputtering [7, 18-21, 62-64, 105]

- electroplating [10, 17-19, 30, 88, 106-112]

- evaporating an element out of the substrate material to create a "glazed" surface [113].

A pressure is usually applied to the bonding assembly to keep the substrates aligned and to promote bonding; specific pressures are categorized in Table 1 by their nearest order of magnitude. For example, pressures in the nearest order range of $10 \mathrm{MPa}[\log (10)=1]$ lie between $3.1623 \mathrm{MPa}$ $[\log (3.1623)=0.5]$ and $31.623 \mathrm{MPa}[\log (31.623)=1.5]$. Occasionally, the substrates are held a fixed distance apart rather than applying a pressure, but this tends to cause porosity in the final bond [6, 19, 43].

Heating of the bond assembly and homogenizing of the bond is performed with many different equipment setups and can occur by the following methods:

- radiation $[4,7,16,17,20,37-43,77-80,105,109,113$, $122,124,130,135-138]$

- conduction [35-37, 83, 95, 129]

- radio-frequency induction $[3,7,11,21-24,60-63,71-$ $76,108,110,125-127,129,139-141]$

- resistance $[46,69,100,110]$

- laser [31]

- infrared [7].

The bonding process is usually confined in a vacuum [3$5,7,12,14-17,20-30,35,38-40,46-58,61-63,65,66$, 68-72, 76-83, 86-88, 93-100, 103-105, 108, 110, 112$115,117,119,122-127,130,132-138,140-157]$, although an inert atmosphere, such as argon, can be used [6, 11, 14, 32, 33, 43, 45, 60, 67, 74, 75, 90, 111, 121, 134, 158, 159]. On rare occasions, TLP bonding is performed under a different atmosphere, such as nitrogen [44], hydrogen [160], nitrogen and hydrogen [18], or open air [129]. The vacuum pressures used in the experiments referenced above are normally distributed about $0.1 \mu \mathrm{mHg}$ (millitorr) with minimum and maximum values of 0.00015 and $34 \mu \mathrm{mHg}$, respectively.

\section{TLP bonding kinetics}

TLP bonding kinetics are generally divided into the following discrete stages $[2,8,25,56,62,86,90,99,105$, $138,141,157,161,162]$ for ease of comprehending and modeling the process:

- melting of the interlayer

- dissolution of the substrate material

- isothermal solidification

- homogenization of the bond region.

Figure 1 is a schematic of TLP bonding kinetics for a binary system with complete solid solubility. ${ }^{1}$ The concentration profiles in the lower part of the figure are numbered according to the current temperature of the bond, which is shown in the phase diagram above them. The following analysis assumes that (1) the interlayer and substrate materials are pure elements (2) the bond region has a uniform temperature as it is being heated (3) the diffusion rates of liquid metals are infinite, and (4) the substrate melts back and solidifies as a plane. The second assumption is likely true since the interlayer is quite thin and generally composed of metallic elements that characteristically have moderate to high thermal conductivities. The third assumption is based on liquid diffusivity data often being orders of magnitude greater than solid diffusivity data [163]. The fourth assumption is necessary to characterize the process in one dimension.

Concentration profile 1 (CP1) in Fig. 1 shows the TLP bonding setup at room temperature. The interlayer element (i) is sandwiched between two pieces of the substrate material element $(s)$. The thickness of the bond region in

\footnotetext{
1 A numerical model was developed to calculate one-dimensional solid-state diffusion in conjunction with a liquid region that expands or contracts, assuming infinite diffusivity for the liquid region. The model also accounts for a heating period and diffusivity data as a function of concentration and temperature. Diffusivity data along with solidus and liquidus profiles for a hypothetical binary system were used to output concentration profiles that were the basis for the concentration profiles in Figs. 1, 3, 5, and 6.
} 
Fig. 1 A schematic binary system with complete solid solubility and associated concentration profiles. These profiles illustrate the interlayer element's concentration during the TLP bonding process
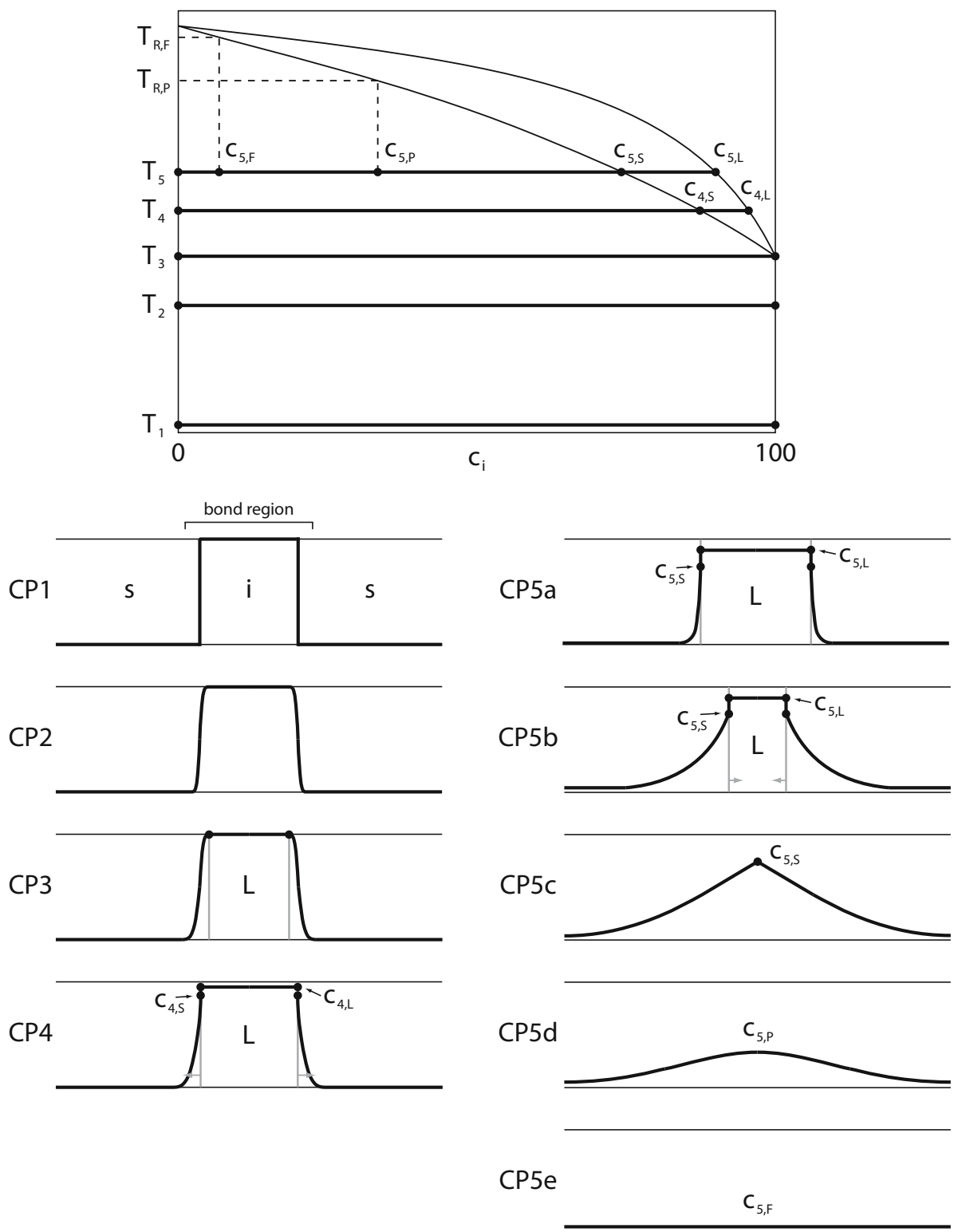

Fig. 1 has been exaggerated to display changes in the concentration profile. The interlayer can be composed of a single element, an alloy, or a multi-layer combination of elements and/or alloys.

Interlayer thicknesses for TLP bonding are summarized in Table 2. Besides the frequency of each range, common thicknesses are also included for those ranges derived from at least ten references. These common thicknesses comprise at least one-third of the specified range and include plus or minus two percent to account for differences between metric and English units (e.g., 0.004 inches equals $101.6 \mu \mathrm{m}$ and should be categorized with $100 \mu \mathrm{m})$. The most common interlayer thickness is $50 \mu \mathrm{m}$, comprising almost $90 \%$ of the $40-60 \mu \mathrm{m}$ range, or about $20 \%$ of all reported TLP bond thicknesses.
As the bond assembly is heated, the interlayer begins to diffuse into the substrate materials (CP2). The amount of diffusion that occurs is dependent upon the interdiffusion coefficient between the substrate and interlayer materials as well as the heating rate.

\section{Melting}

Upon reaching the interlayer element's melting point (CP3), the pure portion of the interlayer liquefies (L). Heating of the bond region continues until the bonding temperature has been reached. The bonding temperature is usually well above the interlayer's melting point to ensure complete melting of the interlayer and to increase the rate of diffusion (see Optimal bonding temperature). 
Table 2 Interlayer thicknesses for TLP bonding

\begin{tabular}{llcc}
$\begin{array}{l}\text { Thickness } \\
\text { range }(\mu \mathrm{m})\end{array}$ & $\begin{array}{l}\text { Common } \\
\text { thickness }(\mathrm{es})(\mu \mathrm{m})\end{array}$ & $\begin{array}{l}\text { Freq. } \\
(\%)\end{array}$ & References \\
\hline$<1$ & & 5 & {$[35,103,130]$} \\
$1-5$ & 1,2 & 10 & {$[20,21,35,54,62-64,102,105,107,108,114,118,129,130,144,164,165]$} \\
$10-30$ & 20,25 & 35 & {$[5,8,10,20-25,34,35,39,44,48,54,59-63,66,68,74-76,78-80,82,87,89,105,107$,} \\
& & & $110,117,118,120-123,126,131,134,137,141-143,145-147,150,152,155,166-171]$ \\
$40-60$ & 50 & 24 & {$[2,5,20,26,27,32,33,36,37,40,42,46,51,52,55-60,64,69-71,77,78,81,83,84,87$,} \\
& & $88,90,101,115,119,124-128,135,136,145,148,149,153,155,157,166,167,172]$ \\
$70-150$ & 75,100 & & {$[4,5,11,14,17,18,22,29,31,38,42-45,49-51,53,78,86,87,109,125,134,135,147$,} \\
& & & $151,155,159,162]$ \\
$200-500$ & 200,500 & 6 & {$[6,16,55,77,95-97,100,104,140,158,159,162,171]$} \\
$>500$ & & 2 & {$[65,97]$} \\
\hline
\end{tabular}

\section{Dissolution}

During heating past the melting point, the concentrations of the liquid region follow the solidus $\left(\mathrm{c}_{4, \mathrm{~S}}\right)$ and liquidus $\left(\mathrm{c}_{4, \mathrm{~L}}\right)$ lines of the phase diagram (CP4). This causes the liquid region to melt back, or dissolve, the substrate material to conserve mass. The movement of the solid-liquid interface continues until the bonding temperature has been reached (CP5a); at this point the liquid has attained its maximum width and has consumed some of the diffused solute. The amount of melt-back is dependent upon the solidus $\left(c_{5, \mathrm{~S}}\right)$ and liquidus $\left(\mathrm{c}_{5, \mathrm{~L}}\right)$ compositions for the given material system at the bonding temperature (see Optimal bonding temperature). The main two effects that lower melt-back distance are (1) significant diffusion of the interlayer material into the substrate before melting (see Critical interlayer thickness) and (2) loss of liquid due to wetting of the substrate's sides [44] or a high bonding pressure that squeezes liquid out [22, 44, 62, 134, 165].

Many materials that are joined by TLP bonding have carefully designed microstructures to achieve certain mechanical properties. Too much melt-back of the substrate by the liquid interlayer can have detrimental effects on the final bond in addition to lengthening the isothermal solidification time (see Critical interlayer thickness). And, in some systems melt-back can reach five to fifteen times the original interlayer thickness $[43,121,146]$. To prevent drastic melt-back that can adversely affect the microstructure, the interlayer should be thin [57, 62], of a eutectic composition [85], or of a composition similar to the substrate material [19].

\section{Solidification}

After the liquid interlayer has reached its maximum width, the interlayer material diffuses into the substrates at a rate somewhere between the diffusivity of the liquid and solid $[25,43,85,163]$. As this diffusion occurs isothermally, the liquid region contracts (CP5b) to conserve mass as the solidus and liquidus concentrations are now fixed. Isothermal solidification occurs until all of the liquid has disappeared $(\mathrm{CP} 5 \mathrm{c})$. At this point, the TLP bonding process can be stopped if desired [71]. The bond already has an elevated remelting temperature $\left(T_{5}\right)$ compared to the melting temperature of the interlayer $\left(T_{3}\right)$.

\section{Homogenization}

In most cases TLP bonding is continued in order to homogenize the bond. This can be an extended time in the same heating apparatus or a post-bond heat treatment applied at some other time [14]. Furthermore, if the substrate material's microstructure is extremely sensitive, this stage can be conducted at a lower temperature $[2,9]$. In either case, the bond undergoes homogenization for some predetermined time which causes smoothing of the solute peak (CP5d) that remained at the end of isothermal solidification (CP5c). The resulting remelting temperature of the bond in this case is $T_{R, P}$. If the peak concentration $\left(c_{5, P}\right)$ is within the room-temperature solid-solubility limit of the binary system, the precipitation of strength-reducing intermetallic compounds upon cooling will be avoided [12, $110,147,150,160]$.

If the bond is homogenized for a sufficient amount of time, there is no gradient in the concentration profile (CP5e) and the bond's remelting temperature is even higher $\left(T_{\mathrm{R}, \mathrm{F}}\right)$. However, despite the increases in bond remelting temperature that can be achieved by complete homogenization, an adequate homogenization time is usually determined by a sufficiently high bond strength [2, $24,26,42,83,103,122,123,146,150]$ or economic considerations that limit furnace time [77, 125, 173]. Nonetheless, the bond's remelting temperature is often hundreds of degrees $\left({ }^{\circ} \mathrm{C}\right)$ above the melting point of the interlayer and can be about $1000{ }^{\circ} \mathrm{C}$ higher if refractory metals such as Ir, Mo, Nb, Os, Re, Ta, or $\mathrm{W}$ are used as the 
substrate or if low melting-point metals such as $\mathrm{Al}, \mathrm{Ga}$, In, $\mathrm{Mg}, \mathrm{Pb}, \mathrm{Sb}, \mathrm{Sn}$, or $\mathrm{Zn}$ are used as the interlayer.

\section{Time frame of TLP bonding}

The time frame of TLP bonding is highly dependent on the material system (e.g., phase diagram particulars, diffusion coefficients, grain size $[18,25,142])$ and the experimental parameters (e.g., interlayer thickness, bonding pressure, bonding temperature). The duration of each discrete stage of TLP bonding lies within the following ranges:

- Heating to the bonding temperature, CP1-5a: less than a minute to about an hour; dependent on the method of heating, the heating rate of the heating apparatus, and the substrate material's thermal properties

- Melting of the interlayer, CP3: less than a second [121, $124,138]$ to several seconds [19, 43, 77]

- Melting back of the substrate, CP3-5a: seconds [11, 71, $73,77,124,138,161,174]$ to minutes [7, 36, 37, 43, $71,73,85,121]$

- Isothermal solidification, CP5a-5c: minutes [7, 25, 36, $37,56,74,77,95,96,105,121,125,153]$ to hours [7, $11,33,36,37,43,57,58,105,146,157,175]$, although it can occur in less than a minute $[73,161]$ or take more than a day [12]

- Homogenization, CP5c-5e: hours [33, 43, 88, 109, 121] to days [88, 175] or, in a few cases, minutes [73].

The general trend is that initial melting of the interlayer occurs an order of magnitude faster than melting back of the substrate, which occurs an order of magnitude faster than isothermal solidification, which occurs an order of magnitude faster than complete homogenization. Isothermal solidification ends up being the limiting, or controlling, time in producing a successful TLP bond [12, 36, 104, 125, $135,138,166,167]$. While the homogenization stage takes longer if carried to completion, it rarely is. As previously stated, homogenization can be performed during a subsequent heat treatment or skipped in some cases; it can even occur once the part is in service.

The foregoing explanation of TLP bonding kinetics also applies to eutectic systems when the interlayer is a eutectic composition alloy. The kinetics are slightly different (and more importantly, TLP bonding takes much longer) for a eutectic system when pure elements are used. (See references $[19,44]$ for particulars of eutectic system kinetics). Tuah-Poku et al. [43] reported a drastic decrease in time to isothermally solidify by changing the interlayer: $200 \mathrm{~h}$ when using the pure element as compared to $8 \mathrm{~h}$ when using the eutectic composition. This occurs because (1) the interlayer has to undergo a certain amount of solid-state diffusion with the substrate at the bonding temperature before any liquid appears and (2) melt-back of the substrate is then greater.

Critical interlayer thickness

During initial heating, the interlayer element diffuses into the substrates. The magnitude of diffusion depends upon the specific material combination, but all solid-state diffusion rates increase as the temperature rises. Depending on the heating rate and the thickness of the interlayer, the amount of diffusion can significantly decrease the interlayer's width. In fact, for a combination of high diffusion rate, slow heating, and/or thin interlayer, it is possible to diffuse all of the interlayer material into the substrate before reaching the interlayer melting point [114, 173], although this is a rare occurrence. Because TLP bonding requires the formation of a bulk liquid phase [9, 109, 114] to create a consolidated, void-free bond while also increasing diffusion rates, the interlayer must exceed a minimum, or critical, thickness [105, 114].

In addition to the parameters listed above, the critical interlayer thickness has been shown to depend on other variables such as applied clamping force, solid/liquid surface tension, surface roughness of the substrate, and intermetallic formation [18, 94, 114]. In short, experiments must be conducted for each material combination to empirically reveal its critical interlayer thickness.

On the other hand, analytical models of TLP bonding indicate that the isothermal solidification process time is roughly proportional to the square of the interlayer thickness $[9,18,19,25,36,44,86,104,110,114,124,138,161$, 173, 175, 176]; experimental data often corroborates this trend $[3,26,43,44,71,86,88,153]$. Therefore, to minimize bonding time, an interlayer slightly thicker than the critical thickness is ideal.

\section{Optimal bonding temperature}

The bonding temperature is sometimes completely limited by the microstructural stability of the substrate material [7, $9,87,125]$. If, however, the substrate material allows flexibility in selecting an optimized bonding temperature, a minimum isothermal solidification time (and therefore bonding time) can be achieved at a certain temperature.

If phase diagram and diffusion data are available for the material system in question, the isothermal solidification time can be characterized with respect to temperature. However, it is usually the case that experiments are the only way to discover this relationship. In general, the relationship is parabolic, yielding a minimum isothermal solidification time at a given intermediate temperature (between the melting points of the interlayer and substrate materials) $[9,18,43,50,78,79,159,162]$. And yet, in 
some cases the variables of the system yield either (1) a monotonically increasing time, in which case the optimal bonding temperature is just above the interlayer's melting point, $[6,9,43,114,158,162]$ or (2) a monotonically decreasing time, in which case the optimal bonding temperature is as high as the substrate material allows $[4,104$, $114,135,141]$.

The behavior of this trend is highly system dependent and results in part from the interplay of the diffusion rate and the phase diagram of the system $[19,43,50]$. As the temperature is increased, the rate of diffusion increases exponentially. In addition, intermetallic regions, which tend to slow down the rate of diffusion $[60,110]$, can often be avoided by raising the temperature. As shown in Fig. 2, $\mathrm{Pb}$ diffusing into $\mathrm{Pd}$ at $400{ }^{\circ} \mathrm{C}\left(T_{1}\right)$ would pass through five intermetallic regions. $T_{2}$ and $T_{3}$ are ideal temperatures for passing through just two and one intermetallic regions, respectively. $T_{4}$ completely avoids the intermetallic regions while still providing a wide solubility range for the liquid to solidify.

In addition to intermetallics, the shape of the solidus and liquidus lines plays an important role in TLP bonding kinetics and the optimal bonding temperature. Figure 3 demonstrates extremes of solidus and liquidus lines in a binary system with complete solid solubility. The composition profiles below each set of phase diagrams demonstrate the initial melting and isothermal solidification behavior of the interlayer for each case. It is assumed that all four systems (1) have the same diffusion coefficient and (2) are heated instantaneously. The latter assumption is accurate for many material systems since complete meltback often consumes much of the solute that has diffused into the substrate (see CP5a in Fig. 1). The top concentration profiles illustrate initial melt-back of a pure interlayer-the dotted line is the initial interlayer and the solid line is the molten interlayer. The bottom concentration profiles illustrate isothermal solidification for all four systems after a set time.

The partition coefficient $(k)$ is included in the diagram and is defined as:

$k=\frac{c_{\mathrm{S}}}{c_{\mathrm{L}}}$

where $c_{\mathrm{S}}$ and $c_{\mathrm{L}}$ are the solidus and liquidus compositions of the interlayer element.

Systems $a$ and $b$ in Fig. 3 have the same convex-shaped liquidus line and therefore experience the same amount of melt-back (see the top concentration profiles). The same is true for the concave-shaped liquidus line in systems $c$ and $d$. Systems $a$ and $c$ have the same partition coefficient (0.9). The same is true for systems $b$ and $d(0.4)$.

A few principles of TLP bonding kinetics can be gleaned from this figure. First, the convex-shaped liquidus line $(a$ and $b)$ prevents melt-back from occurring to a large extent, whereas the concave-shaped liquidus line ( $c$ and d) causes much more melt-back. Second, isothermal
Fig. $2 \mathrm{~Pb}-\mathrm{Pd}$ binary system [177] illustrating bonding temperatures (dotted lines) that avoid intermetallic regions

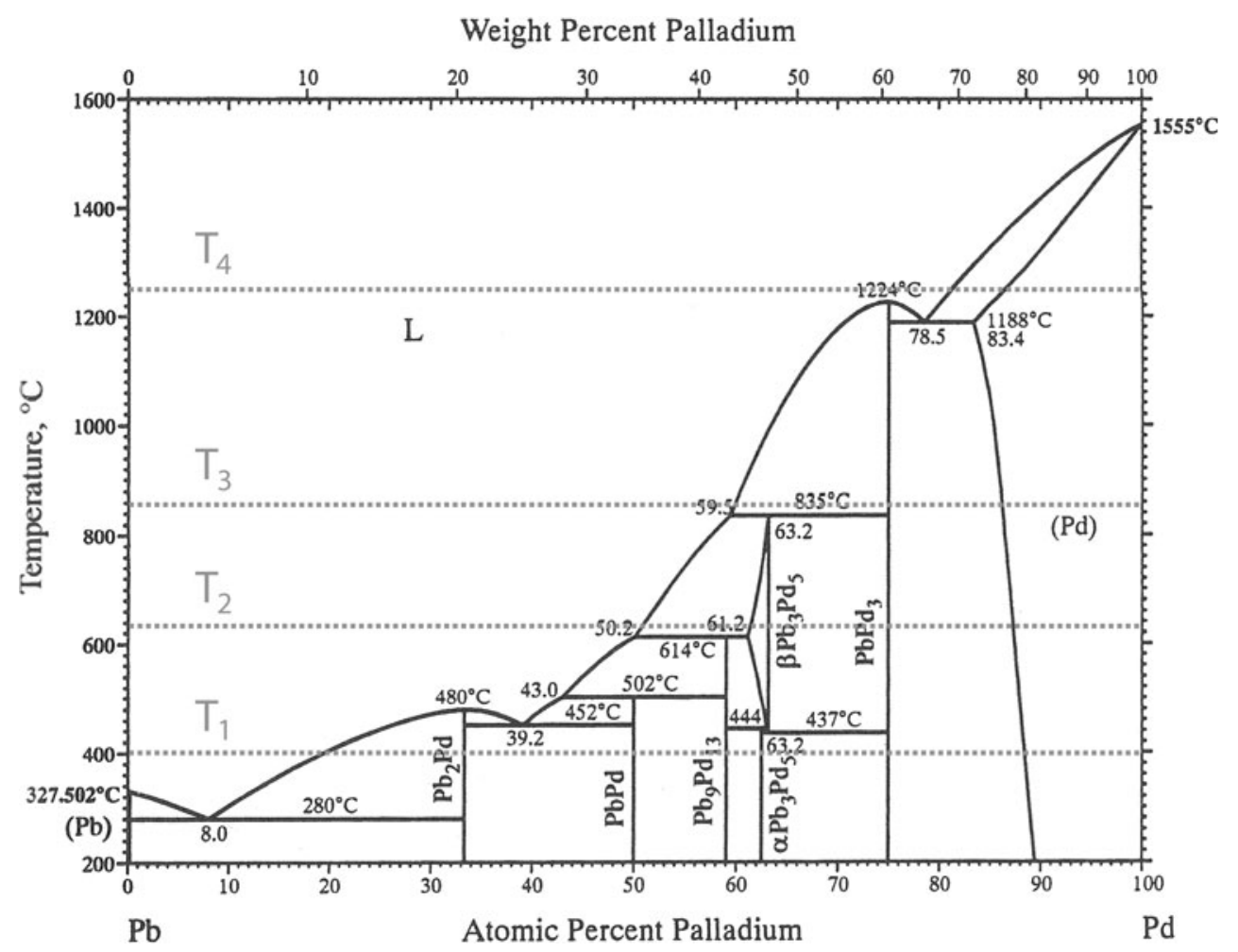


Fig. 3 Four binary systems (ad) with complete solid solubility and associated concentration profiles. These profiles illustrate the initial condition (dotted line), initial melt-back of the substrate, and resulting concentrations after a set amount of TLP bonding has occurred in all four systems. Partition coefficient values are also shown for all four systems at the given bonding temperature
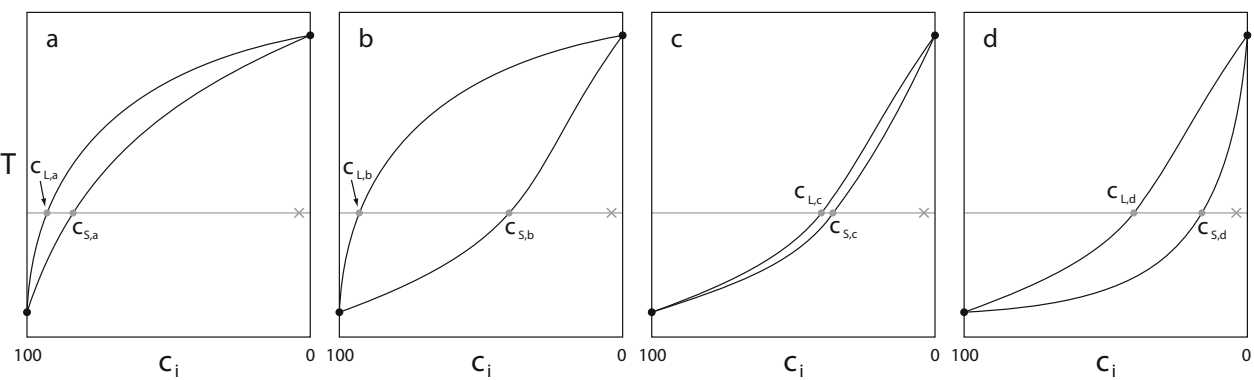

$$
\mathrm{k}_{\mathrm{a}}=\frac{83.7}{93.0}=0.9
$$

$k_{b}=\frac{37.2}{93.0}=0.4$

$\mathrm{k}_{\mathrm{c}}=\frac{36.0}{40.0}=0.9$

$\mathrm{k}_{\mathrm{d}}=\frac{16.0}{40.0}=0.4$

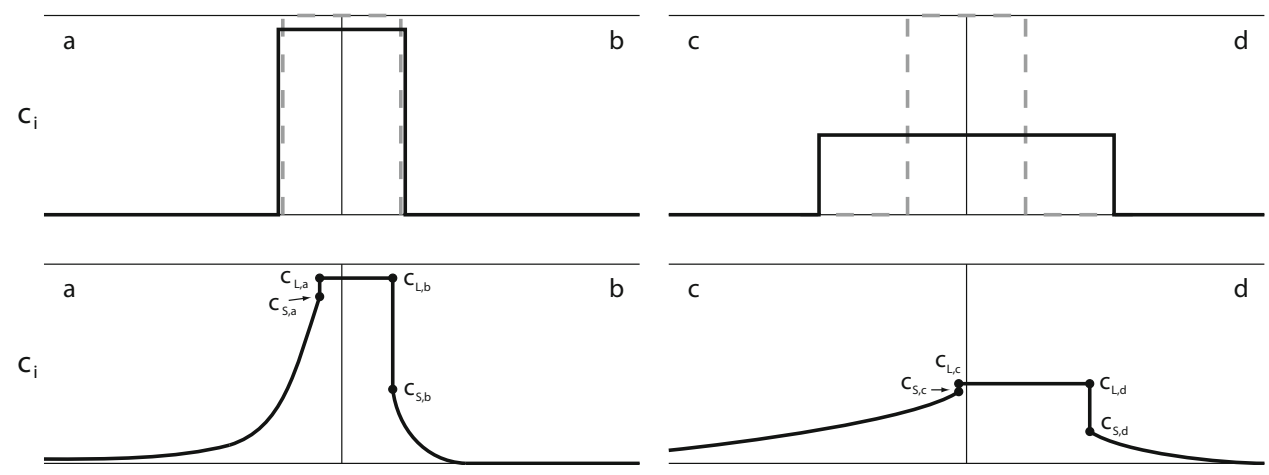

solidification occurs faster in systems with a higher partition coefficient ( $a$ and $c$ ). To conserve mass, the volume of solidified liquid is equal to the change in the concentration profile of the solid region. The width of isothermal solidification in an arbitrary time period is equal to the ratio of this volume to the difference between the liquidus and solidus compositions, or, written another way:

$V_{\text {liq }}=\left(c_{\mathrm{L}}-c_{\mathrm{S}}\right) w_{\text {isoth.solidif. }}$

Although systems $a$ and $c$ have the same partition coefficient, because the liquidus and solidus compositions of system $c$ are closer to zero, they are also closer to each other, causing isothermal solidification to occur slightly faster (see Fig. 3).

If the substrate material has a sensitive microstructure that could be damaged by significant melt-back, then phase diagrams such as systems $c$ and $d$ should be avoided. Systems $b$ and $d$ will take much longer to isothermally solidify, raising operating costs.

Systems $a$ and $c$ are quite similar in rate of isothermal solidification. Because the solidus composition of system $c$ is closer to the completely homogenized composition (shown as an $x$ on the gray line), homogenization of the solute peak after isothermal solidification will likely proceed more rapidly than in system $a$. However, because the solidus line of system $a$ has a convex shape, increases in bond remelting temperature due to homogenization will likely occur faster and be larger in this system.

\section{Modeling of TLP bonding}

Analytical models have been developed by many researchers for the four stages of TLP bonding to provide quick estimates or general trends, such as those illustrated in the previous section. Equations for and descriptions of TLP bonding analytical models are included in references [8, 19, 162, 178]. Assumptions made for these models are similar to those made in this article (see TLP bonding kinetics). In some cases these equations provide good results, but for many systems these simplified, binarysystem approaches do not supply accurate estimates $[5,8$, $38,78,79,86]$. This is due in part to the diffusion coefficients being assumed independent of composition.

Some complexities of TLP bonding are quite difficult to model. For example, grain boundaries can cause isothermal solidification to occur at a different rate than that predicted by analytical models using a bulk diffusion coefficient [25, 36, 37]. Indeed, grain boundary diffusion is faster than bulk diffusion in a certain temperature range (based on the alloy's melting point) [173]. Grain boundary diffusion rates also increase as the substrate material's grain size decreases [179]. Further, grain boundaries can be penetrated by the liquid to cause a non-planar solidification front, thereby increasing the area over which diffusion occurs [5, 11, 18, 138]. See references [180, 181] for more information on the effect of grain boundaries in TLP bonding. 
Another interesting deviation is that isothermal solidification can occur in two different "regimes" [38, 50, 138]. The faster solute element of a multi-component interlayer controls the rate of solidification for the first regime. Then, a second solute element controls the rate of solidification during the second regime, resulting in complex concentration-time profiles.

Numerical models can account for some of the complexities of TLP bonding to accurately predict bonding kinetics [7, 8, 161, 162, 168, 173, 176, 179, 182, 183] and can even be extended to multi-component systems [174, 184]. Despite the complexities and extra time required in numerical modeling, especially for multi-component systems, the limiting factor is most often the lack of necessary diffusion data $[7,8,178]$. But, when the necessary data is available, modeling of TLP bonding can drastically reduce the number of experiments required to determine optimal bonding parameters [37, 162, 166].

\section{Advantages and disadvantages of TLP bonding}

The most distinctive advantage of TLP bonding is that the resulting bond can operate at the bonding temperature or higher temperatures. In other words, materials can be bonded at a temperature equal to or lower than what the assembled part will experience in service. This is especially important for temperature-sensitive materials whose microstructures can be damaged by too much thermal energy input [117] and therefore need to be joined at lower temperatures.

Another advantage is that the resulting TLP bonds often have microstructural, and therefore mechanical, properties similar to the properties of the base materials [7, 12-14, 24, $32,42,49,61,62,75,77,81,95,105,109,115,119,123$, $141,149,153,166,175]$. In fact, in some cases the bond area becomes indistinguishable from other grain boundaries [18, 35, 37, 68, 108, 109, 130, 185] due to significant diffusion at high temperature. Such bonds are often as strong as the bulk substrate material [14, 164], or stronger, causing the joined assembly to fail in the substrate material rather than in the bond $[14,31,71,76]$.

Advantages of TLP bonding include:

- the process is highly tolerant to the presence of a faying surface oxide layer $[2,6,7,11,13,21,42,47,48,56$, $67,80,93,136,147-149,186]$ and therefore requires less joint preparation and no fluxing agents $[11,18,42$, $173,187]$; in a few rare cases surface oxides are actually beneficial to the process [129]

- fixturing pressures are much lower than those used in other joining processes like diffusion bonding [11, 14, 19, 24, 25, 33, 37, 42, 43, 49, 62, 68, 78, 136, 145-149]
- little melting of the substrate material occurs, as compared to fusion welding processes [42, 64]

- many joints can be fabricated in one pass [11, 147]

- the liquid formed during TLP bonding fills voids on uneven mating surfaces, making costly finishing processes unnecessary [2, 14, 18, 19, 33, 49, 161]

- overaging of temperature-sensitive materials can be avoided [80, 140, 186, 188].

For some material systems, bond properties and performance capabilities that are difficult or impractical to achieve using conventional joining methods are more accessible [189].

However, TLP bonding is a specialized bonding technique that can be time-consuming and expensive compared to other joining methods - the time required for isothermal solidification and sufficient bond homogenization can be unfeasibly long and/or uneconomical [36, 37, 104, 141]. TLP bonding is not always suitable, specifically in the following cases:

- significant melt-back of a material with a specifically designed microstructure [7, 62, 141]

- the formation of a thick layer of intermetallic compounds in the bond that tend to lower its strength and ductility [9, 36, 87, 110, 141, 146, 157, 158, 167]

- the segregation of particles in metal matrix composites at the joint centerline, leaving a distinct weakened band in the joint microstructure [19, 33, 39, 42, 54, 105].

See reference [7] for examples of specific difficulties that occur in TLP bonding applications. Although many disadvantages of TLP bonding can be overcome by optimized bonding parameters, the optimization process often requires much experimentation.

\section{Applications of TLP bonding}

Since TLP bonding was developed, it has successfully been applied to join a broad range of materials and structures including the following:

- Al-, Co-, Fe-, Ni-, and Ti-based alloys [7, 10, 11, 24, 43, 47, 54, 65, 85, 109, 154, 173, 190, 191]

- Cellular structures [15, 91]

- Ceramics [114, 173]

- Metal matrix composites [7, 54, 93, 114, 173]

- Microcircuitry components [102, 104, 152, 157, 173, 192, 193]

- Oxide-dispersion-strengthened alloys [7, 24, 65, 125, 126]

- Single crystals [3, 65]

- Stainless steels [25, 47, 54, 85, 190]

- Structural intermetallics [7, 12, 47, 51, 83, 85]. 
TLP bonding is often used in high-stress, high-temperature applications where brazing, welding, and diffusion brazing cannot be used for various reasons (e.g., low melting temperature bond, insufficient resulting mechanical properties, unacceptable plastic deformation) $[4,11,12$, 14, 19, 44, 49-51, 69, 85, 86, 92, 119, 130, 136, 141, 146, 149, 164, 186]. Specific applications are the repair of Nibased superalloy turbine blade components [7, 9, 39, 74, $104,105,135,142]$ and the joining of heat-resistant alloys that are inherently susceptible to hot cracking or post-weld heat treatment cracking $[5,11,20,38,59,78,80,135,136$, 140, 173]. Table 3 presents a spectrum of TLP bonds as of now, including bonds of dissimilar materials.

\section{Variants of TLP bonding}

A few variants of TLP bonding also exist:

- Temperature gradient TLP bonding: the application of a temperature gradient causes a non-planar bond interface which tends to result in stronger bonds [8, 21, 164, 186, 194]

- Wide-gap TLP bonding: gaps of 100-500 $\mu \mathrm{m}$ can be bonded or repaired by the use of a melting and a nonmelting constituent (multiple layers or mixed powders) [7, 16, 57, 92, 94-96, 100, 101, 136, 149, 173, 195]. This technique can also be used in conventional TLP bonding to accelerate isothermal solidification [13, 99, 140]

- Active TLP bonding: a ceramic and metal can be joined by a multi-component interlayer; at least one constituent reacts with the ceramic while another diffuses into the metal to cause isothermal solidification [28, 42, 52, 54, 116, 132, 196]

- Partial TLP bonding (see next section).

Bonds made using temperature gradient, wide-gap, and active TLP bonding have been included in Table 3 .

\section{Partial transient liquid phase (PTLP) bonding}

Partial transient liquid phase (PTLP) bonding is a variant of TLP bonding mainly used to join ceramics. PTLP bonding overlaps both wide-gap and active TLP bonding, although articles defining PTLP bonding predate the other two techniques by a few years. Many advantages of conventional TLP bonding carry over to PTLP bonding [188]. The ensuing sections focus on how PTLP bonding differs from TLP bonding.

\section{PTLP bonding process}

In PTLP bonding, the interlayer consists of thin layers of low-melting-point metals or alloys on each side of a much thicker refractory metal or alloy layer [188, 200-203]. Figure 4 presents a general, three-layer PTLP bond setup. (In some cases, there can be multiple thin layers on each side of the refractory core (see Table 4), but the general principles of the process remain the same.) Upon heating to the bonding temperature, a liquid is formed (through melting or a eutectic reaction with the refractory core [202-206]) by each thin layer. The liquid that is formed wets each ceramic substrate while concomitantly diffusing into the solid refractory core. As in TLP bonding, the liquid regions solidify isothermally and homogenization of the entire bond region leads to a refractory bond.

The refractory core tends to be a foil that is $20-30 \mu \mathrm{m}$ [143, 207-214] or 100-127 $\mu \mathrm{m}$ thick [116, 188, 189, 201, 207, 211-213, 215-222], although it can be in the 200-1000 $\mu \mathrm{m}$ range $[202-205,208,223-225]$. The refractory core element is often $\mathrm{Ni}[144,189,196,201-$ 204, 207-210, 218, 224, 226, 227]; other elements (and an alloy) that have been used include $\mathrm{Au}, \mathrm{Co}, \mathrm{Cu}, \mathrm{Nb}, \mathrm{Ni}-\mathrm{Cr}$, Pd, Pt, Si, Ta, Ti, and V [117, 188, 189, 200-202, 205-208, 214-218, 222, 227-229]. The thin layers can be most of the formats used for TLP bonding interlayers (see TLP bonding process) and are often in the $1-10 \mu \mathrm{m}$ thick range. The ratio of the thin layer thickness over the refractory core thickness is usually $1-5 \%$ [143, 188, 189, 201-204, 207, 208, 211-213, 215-218, 220, 222-225, 230, 231], although it can be 6-20\% [207, 210-213, 219, 221, 223], and some PTLP bond experiments have utilized a ratio of $50 \%$ or higher [116, 144, 208, 214, 226].

\section{PTLP bonding kinetics}

Figures 5 and 6 depict the two ends of the PTLP bonding process. The following additional assumptions are made in this analysis: (1) thin layer $\mathrm{A}\left(\mathrm{tl}_{\mathrm{A}}\right)$, the refractory core ( $\mathrm{rc}$ ), and thin layer $\mathrm{B}\left(\mathrm{tl}_{\mathrm{B}}\right)$ are different pure elements (2) there is no diffusion into the ceramic substrates (3) the ternary system $\left(\mathrm{tl}_{\mathrm{A}}-\mathrm{rc}-\mathrm{tl}_{\mathrm{B}}\right)$ can be approximated by the two associated binary systems $\left(\mathrm{tl}_{\mathrm{A}}-\mathrm{rc}\right.$ and $\left.\mathrm{rc}-\mathrm{tl}_{\mathrm{B}}\right)$, and (4) the interlayers wet the substrate with a thin layer of intermetallic formation that conserves the amount of liquid and results in a refractory intermetallic.

The second and fourth assumptions highlight the major differences between TLP and PTLP bonding. First, the multi-layer interlayer used during PTLP bonding has been termed "self-contained" [215] because the liquid phases must diffuse into the rc, rather than the much larger substrate materials, to induce isothermal solidification. Second, the liquid phases must wet the ceramic substrates to create a strong bond. This tends to be difficult due to the chemical inertness of ceramics $[117,180,196,216]$ and usually requires the use of active elements such as $\mathrm{Al}, \mathrm{Cr}$, Hf, Nb, Ni, Sc, Ta, Ti, V, or Zr [65, 117, 187, 189, 198, 
Table 3 A spectrum of materials joined by TLP bonding

\begin{tabular}{|c|c|c|}
\hline Substrate $^{\mathrm{a}}$ & Interlayer $(\mathrm{s})^{\mathrm{b}}$ & Reference(s) \\
\hline \multicolumn{3}{|l|}{ Ni-based alloys } \\
\hline GTD-111 & MBF-30, MBF-50 & {$[3,68,79,82]$} \\
\hline Inconel 600 & NB 150 & {$[135]$} \\
\hline Inconel 617 & BNi-3, BNi-6 & {$[147,156]$} \\
\hline Inconel 625 & BNi-2 & [104] \\
\hline Inconel 713C & BNi-6 & {$[88]$} \\
\hline Inconel 718 & $\mathrm{BNi}-2$ & {$[104]$} \\
\hline Inconel 738 & $\begin{array}{l}\text { NB 30, NB 150, BNi-3, MBF-60, MBF-80, } \\
\text { DF-3 }\end{array}$ & $\begin{array}{l}{[5,38,45,66,78,80,86} \\
\quad 87,159,162,178]\end{array}$ \\
\hline Inconel MA758 & $\mathrm{Ni}-\mathrm{B}, \mathrm{Ni}-\mathrm{Cr}-\mathrm{Si}-\mathrm{Fe}-\mathrm{B}, \mathrm{MBF}-80$ & {$[24,108,125,141]$} \\
\hline Inconel MA760 & $\mathrm{Ni}-\mathrm{Cr}-\mathrm{P}, \mathrm{Ni}-\mathrm{Cr}-\mathrm{Si}-\mathrm{Fe}-\mathrm{B}$ & {$[64]$} \\
\hline Inconel 939 & F20, F24, F25, F26, F27, MBF-80 & {$[59]$} \\
\hline Mar-M247 & F20, F24, F25, F26, F27, MBF-80 & [59] \\
\hline Nimonic 80A & NilNB $125 \mid N i$ & [109] \\
\hline René N5 & $\mathrm{Ni}-\mathrm{Ge}, \mathrm{Ni}-\mathrm{Mn}, \mathrm{Ni}-\mathrm{Mn}-\mathrm{Si}, \mathrm{D}-15$ & {$[6,16,158]$} \\
\hline Udimet 700 & $\mathrm{Ni}-\mathrm{Cr}-\mathrm{Co}-\mathrm{Mo}-\mathrm{B}$ & {$[14]$} \\
\hline Waspaloy & NB 150 & {$[38,50,178]$} \\
\hline $\mathrm{Ni}-6.4 \mathrm{Al}$ & $\mathrm{Ni}-\mathrm{B}$ & {$[157]$} \\
\hline $\mathrm{Ni}-15 \mathrm{Cr}-11.5 \mathrm{Al}-3 \mathrm{~W}-0.2 \mathrm{Hf}-0.1 \mathrm{Si}-0.1 \mathrm{Mn}\left(\gamma / \gamma^{\prime} / \beta\right.$ type $)$ & $\begin{array}{l}\text { MBF- } 80, \mathrm{Ni}-\mathrm{Cr}-\mathrm{B}-\mathrm{Ce} \text { (various } \\
\text { combinations) }\end{array}$ & {$[65]$} \\
\hline \multicolumn{3}{|l|}{ Al-based alloys } \\
\hline Al A356.0 & $\mathrm{Cu}$ & {$[107]$} \\
\hline Al 5052 & $\mathrm{Ag}-\mathrm{Cu}$ & {$[127]$} \\
\hline Al 6060 & $\mathrm{Al}-\mathrm{Cu}, \mathrm{Al}-\mathrm{Si}-\mathrm{Cu}$ & {$[165]$} \\
\hline Al 6061 & $\mathrm{Ag}, \mathrm{Al}-\mathrm{Si}, \mathrm{BAg}-8$ & {$[17,27]$} \\
\hline Al 6082 & $\mathrm{Cu}, \mathrm{Ga}$ & {$[21,129,164]$} \\
\hline Al 7475 & $\mathrm{Zn}$ & {$[30]$} \\
\hline $\mathrm{Al}-7.5 \mathrm{Si}$ & $\mathrm{Cu}$ & {$[107]$} \\
\hline \multicolumn{3}{|l|}{ Fe-based alloys } \\
\hline $304 \mathrm{SS}^{\mathrm{c}}$ & $\mathrm{Ni}-\mathrm{Cr}, 304 \mathrm{~L} \mathrm{SS}{ }^{\mathrm{c}}, \mathrm{BNi}-2$ & {$[77,99]$} \\
\hline $304 \mathrm{~L} \mathrm{SS}^{\mathrm{c}}$ & NB 51 & [91] \\
\hline Duplex $\mathrm{SS}^{\mathrm{c}}$ & $\begin{array}{l}\mathrm{Cu}, \mathrm{Fe}-\mathrm{B}-\mathrm{Si}, \mathrm{Ni}-\mathrm{Si}-\mathrm{B}, \mathrm{MBF}-20, \mathrm{MBF}-30, \\
\text { MBF-35, MBF-50, MBF-80 }\end{array}$ & {$[25,47,61,76,153,169]$} \\
\hline Carbon steel & $\mathrm{Cu}, \mathrm{Fe}-\mathrm{B}$ & {$[36,37,74]$} \\
\hline $\mathrm{Fe}-\mathrm{Ni}-\mathrm{Cr}$ & $\mathrm{Ni}-\mathrm{B}-\mathrm{Cr}-\mathrm{Si}$ (various combinations) & {$[133]$} \\
\hline Incoloy MA956 & $\mathrm{B}, \mathrm{Fe}-\mathrm{B}-\mathrm{Si}$ & {$[35,63,65,130]$} \\
\hline Incoloy MA957 & $\mathrm{Fe}-\mathrm{B}-\mathrm{Si}, \mathrm{BNi}-1 \mathrm{a}, \mathrm{BNi}-3$ & {$[62,63,126]$} \\
\hline Low carbon steel & $\mathrm{Fe}-\mathrm{B}-\mathrm{Si}, \mathrm{BNi}-2$ & {$[67,75]$} \\
\hline $\mathrm{ODS}^{\mathrm{c}}$ steel $\left(\mathrm{Fe}-\mathrm{Cr}-\mathrm{W}-\mathrm{Y}_{2} \mathrm{O}_{3}-\mathrm{Ti}\right)$ & $\mathrm{Fe}-\mathrm{Si}-\mathrm{B}$ & {$[131]$} \\
\hline PM2000 (Fe-Cr-Al) & $\mathrm{B}, \mathrm{Fe}-\mathrm{B}-\mathrm{Si}$ & {$[35,63,130]$} \\
\hline T91 steel & $\mathrm{Fe}-\mathrm{B}-\mathrm{Si}, \mathrm{Fe}-\mathrm{Ni}-\mathrm{Cr}-\mathrm{Si}-\mathrm{B}, \mathrm{BNi}-2$ & {$[60]$} \\
\hline \multicolumn{3}{|l|}{ Ti-based alloys } \\
\hline OT4 & $\mathrm{Cu}-\mathrm{Ti}, \mathrm{Ni}-\mathrm{Ti}, \mathrm{Ti}-\mathrm{Cu}-\mathrm{Zr}$ & {$[97,134]$} \\
\hline VT1 & $\mathrm{Cu}$ & {$[46]$} \\
\hline Ti-6Al-4 V & $\mathrm{Cu}$ & [34] \\
\hline $\mathrm{Ti}-22 \mathrm{Al}-25 \mathrm{Nb}$ (a) & $\mathrm{Ti}-\mathrm{Cu}-\mathrm{Ni}$ & {$[83]$} \\
\hline \multicolumn{3}{|l|}{ Miscellaneous alloys } \\
\hline AZ31 (Mg-Al-Zn) & $\mathrm{Al}, \mathrm{Cu}$ & {$[121,150]$} \\
\hline K640 (Co-Cr-Mo) & $\mathrm{Co}-\mathrm{Ni}-\mathrm{Cr}-\mathrm{W}-\mathrm{B}-\mathrm{Si}$ & [2] \\
\hline
\end{tabular}


Table 3 continued

\begin{tabular}{|c|c|c|c|}
\hline \multicolumn{2}{|l|}{ Substrate $^{a}$} & Interlayer $(\mathrm{s})^{\mathrm{b}}$ & Reference(s) \\
\hline \multicolumn{2}{|l|}{ Co alloy (unspecified) } & $\mathrm{Ni}-\mathrm{Cr}-\mathrm{B}$ & {$[10]$} \\
\hline \multicolumn{2}{|l|}{$\mathrm{Cu}\left(\mathrm{ODS}^{\mathrm{c}}\right)$} & $\mathrm{Cu}|\mathrm{Sn}| \mathrm{Cu}$ & {$[110,151]$} \\
\hline \multicolumn{2}{|l|}{$\mathrm{Cu}-\mathrm{Cr}-\mathrm{Zr}$} & $\mathrm{Cu}|\mathrm{Sn}| \mathrm{Cu}$ & [110] \\
\hline \multicolumn{2}{|l|}{$\mathrm{Sn}-\mathrm{Ag}$} & $\mathrm{Sn}-\mathrm{Bi}, \mathrm{Bi}-\mathrm{Sn}$ (various combinations) & {$[106]$} \\
\hline \multicolumn{4}{|l|}{ Single crystals } \\
\hline \multicolumn{2}{|l|}{$\mathrm{Ni}$} & $\mathrm{Ni}-\mathrm{P}$ & [142] \\
\hline \multicolumn{2}{|l|}{ CMSX-2 } & F24, MBF-80 & {$[26,70,71]$} \\
\hline \multicolumn{2}{|l|}{ CMSX-4 } & D-15, MBF-80 & {$[9,26]$} \\
\hline \multicolumn{2}{|c|}{ IC 6 (with and without B) } & MBF-80 & {$[53]$} \\
\hline \multicolumn{2}{|c|}{ PWA 1483 (Ni-Cr-Co-Ta-Ti-W-Al-Mo) } & $\mathrm{Ni}-\mathrm{Ge}$ & {$[6,158]$} \\
\hline \multicolumn{4}{|l|}{ Intermetallics } \\
\hline \multicolumn{2}{|l|}{$\mathrm{Ni}-45 \mathrm{Ti}-6 \mathrm{Cu}$} & $\mathrm{Cu}$ & {$[32]$} \\
\hline \multicolumn{2}{|l|}{$\mathrm{NiAl}$} & $\mathrm{Ni}$ (glaze), BNi-3 & {$[84,113]$} \\
\hline \multicolumn{2}{|l|}{$\mathrm{Ti}-42 \mathrm{Al}-2 \mathrm{Cr}$} & $\mathrm{Ti}|\mathrm{Cu}, \mathrm{Ti}| \mathrm{Ni}, \mathrm{Ti} \mid \mathrm{Fe}$ & {$[51]$} \\
\hline \multicolumn{2}{|c|}{$\mathrm{Ti}-45 \mathrm{Al}-2 \mathrm{Nb}-2 \mathrm{Mn}(\mathrm{a})+0.8$ vol. $\% \mathrm{TiB}_{2}$} & $\mathrm{Ti}-\mathrm{Cu}-\mathrm{Ni}, \mathrm{Cu}-\mathrm{Ni}|\mathrm{Ti}| \mathrm{Cu}-\mathrm{Ni}$ & {$[20]$} \\
\hline \multicolumn{2}{|c|}{$\gamma$-TiAl [Ti-47Al-2Cr-2Nb (a)] } & Tini 67 & {$[40]$} \\
\hline \multicolumn{2}{|l|}{$\mathrm{Ti}-48 \mathrm{Al}-2 \mathrm{Cr}-2 \mathrm{Nb}$ (a) } & $\mathrm{Cu}, \mathrm{Cu} \& \mathrm{Ti}-\mathrm{Al}-\mathrm{Cr}-\mathrm{Nb}, \mathrm{Cu} \& \mathrm{TiAl}$ & {$[94,96,100,197]$} \\
\hline \multicolumn{2}{|l|}{ Gamma Met PX } & $\mathrm{Cu} \&$ Gamma Met & {$[95]$} \\
\hline \multicolumn{4}{|l|}{ Pure metals } \\
\hline \multicolumn{2}{|l|}{$\mathrm{Ag}$} & $\mathrm{Cu}, \mathrm{Ag}-\mathrm{Cu}$ & {$[8,43,44]$} \\
\hline \multicolumn{2}{|l|}{$\mathrm{Al}$} & $\mathrm{Ag}, \mathrm{Cu}, \mathrm{Ga}, \mathrm{Al}-\mathrm{Cu}, \mathrm{Al}-\mathrm{Si}-\mathrm{Cu}$ & $\begin{array}{l}{[22,129,148,164,165} \\
\quad 186]\end{array}$ \\
\hline \multicolumn{2}{|l|}{$\mathrm{Au}$} & $\mathrm{Au}-\mathrm{Sn}, \mathrm{Sn}, \mathrm{In}, \mathrm{Ti} \mid \mathrm{In}$ & {$[102,152,198]$} \\
\hline \multicolumn{2}{|l|}{$\mathrm{Cu}$} & $\underset{51}{\mathrm{Ag}, \mathrm{Sn}, \mathrm{Ag}-\mathrm{Cu}, \mathrm{BiIn}, \mathrm{BiIn}_{2}, \mathrm{BiSn}, \mathrm{InSn}, \mathrm{NB}}$ & $\begin{array}{l}{[15,18,44,114,139,160} \\
187,192,198]\end{array}$ \\
\hline $\mathrm{Fe}$ & & $\mathrm{Sb}, \mathrm{Fe}-\mathrm{P}, \mathrm{Fe}-\mathrm{B}$ & {$[137,140]$} \\
\hline $\mathrm{Nb}$ & & $\mathrm{Ti}, \mathrm{Zr}, \mathrm{V}$ & {$[155]$} \\
\hline $\mathrm{Ni}$ & & B, Cu, Hf, BNi-3, BNi-6, MBF-60, MBF-80 & $\begin{array}{l}{[4,81,88,117,138,162} \\
\quad 167,168]\end{array}$ \\
\hline $\mathrm{Sn}$ & & $\mathrm{Bi}$ & [103] \\
\hline Metal matrix comp & $\operatorname{tes}^{\mathrm{d}}$ & & \\
\hline $\mathrm{Al} / \mathrm{Al}_{2} \mathrm{O}_{3}$ & & $\mathrm{Ag}, \mathrm{Cu}, \mathrm{Al}-\mathrm{Cu}, \mathrm{Cu}-\mathrm{Ti}$ & {$[22,42]$} \\
\hline $\mathrm{Al} / \mathrm{SiC}$ & & $\mathrm{Cu}, \mathrm{Ni}$ & {$[144]$} \\
\hline Al 2124/SiC & & $\mathrm{Ni}$ & {$[48]$} \\
\hline Al 2618/SiC & & $\mathrm{Al}-\mathrm{Ag}-\mathrm{Cu}, \mathrm{Al}-\mathrm{Ag}-\mathrm{Cu}-\mathrm{Ti}$ & {$[93,98]$} \\
\hline $\mathrm{Al} 6061 / \mathrm{Al}_{2} \mathrm{O}_{3}$ & & $\mathrm{Cu}$ & {$[39,105,145,146]$} \\
\hline $\mathrm{Al} 6061 / \mathrm{SiC}$ & & $\mathrm{Cu}$ & {$[33,90]$} \\
\hline AZ91D $(\mathrm{Mg}-\mathrm{Al}) / \mathrm{Ti}$ & & $\mathrm{Al}, \mathrm{Cu}$ & {$[122,123]$} \\
\hline Haynes $230 / \mathrm{Al}_{2} \mathrm{O}_{3}$ & & Haynes 230 doped with B & {$[85]$} \\
\hline $\mathrm{Ti}-6 \mathrm{Al}-4 \mathrm{~V} / \mathrm{SiC}$ & & $\mathrm{Cu}-\mathrm{Ti}-\mathrm{Zr}$ & {$[73]$} \\
\hline Ceramics & & & \\
\hline $\mathrm{Al}_{2} \mathrm{O}_{3}$ & & $\mathrm{Al}, \mathrm{Al} \& \mathrm{SiO}_{2}, \mathrm{~B}_{2} \mathrm{O}_{3}$ & {$[118,143,170,199]$} \\
\hline $\mathrm{SiC}$ & & $\mathrm{Ge}$ & [171] \\
\hline $\mathrm{Si}_{3} \mathrm{~N}_{4}$ & & Oxynitride glass & [185] \\
\hline $\mathrm{TiO}_{2}$ & & $\mathrm{Bi}_{2} \mathrm{O}_{3}$ & [89] \\
\hline Dissimilar metals & & & \\
\hline Al 7075 & Ti-6Al-4 V & $\mathrm{Cu}$ & {$[23]$} \\
\hline Astroloy & Mar-M247 (directionally solidified) & $\mathrm{BNi}-3$ & [124] \\
\hline AZ31 (Mg-Al-Zn) & $316 \mathrm{~L} \mathrm{SS}^{\mathrm{c}}$ & $\mathrm{Ni}$ & {$[120]$} \\
\hline
\end{tabular}


Table 3 continued

\begin{tabular}{|c|c|c|c|}
\hline \multicolumn{2}{|l|}{ Substrate $^{\mathrm{a}}$} & \multirow{2}{*}{$\frac{\text { Interlayer(s) }}{\mathrm{Cu}|\mathrm{Sn}| \mathrm{Cu}}$} & \multirow{2}{*}{$\begin{array}{l}\text { Reference(s) } \\
{[110]}\end{array}$} \\
\hline $\mathrm{Be}$ & $\mathrm{Cu}-\mathrm{Cr}-\mathrm{Zr}$ and $\mathrm{Cu}\left(\mathrm{ODS}^{\mathrm{c}}\right)$ & & \\
\hline $\mathrm{Cu}$ & $\mathrm{Cu}-\mathrm{W}$ composite & $\mathrm{Al}$ & {$[31]$} \\
\hline $\mathrm{Cu}$ & Steel & BAg-8 & {$[160]$} \\
\hline $\mathrm{Cu}$ & $304 \mathrm{SS}^{\mathrm{c}}$ & $\mathrm{Ag}$ & {$[10]$} \\
\hline $\mathrm{Cu}$ & $304 \mathrm{~L} \mathrm{SS}^{\mathrm{c}}$ & $\mathrm{Ag}$ & [109] \\
\hline Br.Kh. $(\mathrm{Cu}-\mathrm{Cr})$ & $12 \mathrm{Kh} 18 \mathrm{~N} 10 \mathrm{~T}(\mathrm{Fe}-\mathrm{Cr}-\mathrm{Ni})$ & $\mathrm{Cu}-\mathrm{Mn}|\mathrm{Ni}, \mathrm{Cu}-\mathrm{Ag}| \mathrm{Ni}$ & [111] \\
\hline CMSX-4 & Inconel 738 and 939 & BNi-3, Niflex-110, Niflex-115 & {$[136,149]$} \\
\hline $\begin{array}{l}\text { DD98 (Ni-W-Co- } \\
\text { Mo-Ti-Al-Ta-Hf) }\end{array}$ & M963 (Ni-W-Co single crystal) & $\mathrm{Ni}-\mathrm{Cr}-\mathrm{B}$ & [128] \\
\hline Inconel 718 & Inconel X-750 & $\mathrm{BNi}-2$ & {$[11]$} \\
\hline Mar-M247 & $\mathrm{NiAl}$ & $\mathrm{Cu}$ & {$[12,55,57,58]$} \\
\hline Mar-M247 & NiAl-Hf (single crystal) & $\mathrm{Cu}, \mathrm{NiAl} \& \mathrm{Cu}, \mathrm{Ni}_{3} \mathrm{Al} \& \mathrm{Cu}$ & {$[55-57,92,101]$} \\
\hline $\mathrm{Ni}$ & $\mathrm{NiAl}$ & $\mathrm{Cu}, \mathrm{BNi}-3$ & {$[12,55,57,58,69,115]$} \\
\hline Low carbon steel & $\mathrm{Ti}$ & $\mathrm{Cu}-\mathrm{Mn}-\mathrm{Ni}$ & [49] \\
\hline $\mathrm{SS}^{\mathrm{c}} 321$ & Zircaloy-4 (Zr-Sn) & $\mathrm{Ti}-\mathrm{Zr}-\mathrm{Cu}-\mathrm{Ni}$ & [172] \\
\hline Steel & $304 \mathrm{~L} \mathrm{SS}^{\mathrm{c}}$ & $\mathrm{Cu}$ & {$[160]$} \\
\hline TS7 (Ti alloy) & $\begin{array}{l}\text { 5VMTs (Nb alloy) with } \mathrm{W}, \mathrm{Mo}, \& \mathrm{Zr} \text {; and } \\
\text { TV10 (Ta alloy) with W }\end{array}$ & $\mathrm{Cu}-\mathrm{Ni}$ & [112] \\
\hline $\mathrm{Ti}-42 \mathrm{Al}-2 \mathrm{Cr}$ & Ti 6242 & $\mathrm{TilCu}, \mathrm{Cu} / \mathrm{Ti}$ & [29] \\
\hline Ti-6Al-4 V & $\mathrm{Ti}-45 \mathrm{Al}-2 \mathrm{Nb}-2 \mathrm{Mn}(\mathrm{a})+0.8$ vol. $\% \mathrm{TiB}_{2}$ & $\mathrm{Cu}-\mathrm{Ni}, \mathrm{Ti}-\mathrm{Cu}-\mathrm{Ni}$ & {$[20]$} \\
\hline \multicolumn{4}{|c|}{ Metals to Metal matrix composites ${ }^{\mathrm{d}}$} \\
\hline Al 6082 & Al 359/SiC & $\mathrm{Cu}$ & {$[21]$} \\
\hline Ti-6Al-4 V & $\mathrm{Ti}-6 \mathrm{Al}-4 \mathrm{~V} / \mathrm{SiC}$ & $\mathrm{Cu}-\mathrm{Ti}-\mathrm{Zr}$ & {$[73]$} \\
\hline \multicolumn{4}{|l|}{ Metals to Ceramics } \\
\hline Kovar $(\mathrm{Fe}-\mathrm{Ni}-\mathrm{Co})$ & $\mathrm{SiC}$ & $\mathrm{Ni}-\mathrm{Si} \mid \mathrm{Mo}$ & [116] \\
\hline $\begin{array}{l}\mathrm{ODS}^{\mathrm{c}} \mathrm{Fe} \text { alloy }(\mathrm{Fe}-\mathrm{Cr}- \\
\left.\mathrm{Al}-\mathrm{Y}_{2} \mathrm{O}_{3}\right)\end{array}$ & $\mathrm{Si}_{3} \mathrm{~N}_{4}$ & $\mathrm{Fe}-\mathrm{B}-\mathrm{Si}$ & {$[72]$} \\
\hline $\mathrm{W} 18 \mathrm{Cr} 4 \mathrm{~V}$ tool steel & TiC- $-\mathrm{Al}_{2} \mathrm{O}_{3}$ composite & CulTi & {$[28]$} \\
\hline Inconel 718 & $\mathrm{Si}_{3} \mathrm{~N}_{4}$ & NilCulTi & [196] \\
\hline $\mathrm{Ni}$ & $\mathrm{Ti}(\mathrm{C}, \mathrm{N})(50 \% \mathrm{TiC} \& 50 \% \mathrm{TiN})$ & $\mathrm{CulNb}$ & [132] \\
\hline $\mathrm{Ti}$ & AlN & $\mathrm{Ag}-\mathrm{Cu}$ & {$[52]$} \\
\hline \multicolumn{4}{|c|}{ Metal matrix composites ${ }^{\mathrm{d}}$ to ceramics } \\
\hline $\mathrm{Al} 6061 / \mathrm{Al}_{2} \mathrm{O}_{3}$ & $\mathrm{Al}_{2} \mathrm{O}_{3}$ & $\mathrm{Cu}$ & {$[39,54]$} \\
\hline
\end{tabular}

a Substrate material compositions are in weight percent, unless specified by an (a) for atomic percent

${ }^{\mathrm{b}}$ Interlayer material compositions are notated as either (1) $\mathrm{X}-\mathrm{Y}-\mathrm{Z}$ where $\mathrm{X}$ is the base element and $\mathrm{Y}$ and $\mathrm{Z}$ are alloying elements of at least one weight percent in order of descending composition or (2) one of the following braze alloy designations in weight percent: $\mathrm{BAg}-8(\mathrm{Ag}-28 \mathrm{Cu})$, D-15 (Ni-15.3Cr-10.3Co-3.5Ta-3.5Al-2.3B), DF-3 (Ni-20Co-20Cr-3B-3Ta), F20 (Ni-21.6Cr-17.6Co-3.1 W-2.8Al-2.2B-1.3Ta), F24 (Ni-10.8Co-8.8Cr-3.9 W-3Al-3Ta-2.5B), F25 (Ni-9.8Co-8.6Cr-8.2 W-2.4B), F26 (Ni-9.2Co-8.6Cr-4.9Al-3.6B-2.7Ta), F27 (Ni-9.8Co7.5Cr-3.3B-1.9 W), BNi-1a (Ni-14Cr-4.5Fe-4.5Si-3B), MBF-20 or BNi-2 (Ni-7Cr-4.5Si-3.2B-3Fe), MBF-30 or BNi-3 (Ni-4.5Si-3.2B), MBF-35 (Ni-7.3Si-2.2B), MBF-50 (Ni-19Cr-7.3Si-1.5B), MBF-60 or BNi-6 (Ni-11P), MBF-80 (Ni-15.2Cr-4B), NB 30 (Ni-19Cr-10Si), NB $51(\mathrm{Ni}-25 \mathrm{Cr}-10 \mathrm{P})$, NB $125(\mathrm{Ni}-14 \mathrm{Cr}-4.5 \mathrm{Fe}-4.5 \mathrm{Si}-3.13 \mathrm{~B}), \mathrm{NB} 150(\mathrm{Ni}-15 \mathrm{Cr}-3.5 \mathrm{~B})$, Niflex-110 and Niflex-115 (proprietary), Ticusil $(\mathrm{Ag}-26.7 \mathrm{Cu}-4.5 \mathrm{Ti})$, Tini $67(\mathrm{Ti}-33 \mathrm{Ni})$

c $O D S$ oxide dispersion-strengthened, SS stainless steel

${ }^{\mathrm{d}}$ Metal matrix composites are notated as $\mathrm{X} / \mathrm{Y}$ where $\mathrm{X}$ is the matrix material and $\mathrm{Y}$ is the composite fiber material

200-202, 206, 215, 216, 218, 222, 228, 232, 233]. Also, when analyzing the critical interlayer thickness of the thin layers, a portion of the liquid that forms from those thin layers will react with the ceramic substrate and add to the critical thickness.
The PTLP bonding setup at room temperature is shown in Figs. 5 and 6 as concentration profiles $1_{\mathrm{A}}$ and $1_{\mathrm{B}}, \mathrm{CP} 1_{\mathrm{A}}$ and $\mathrm{CP} 1_{\mathrm{B}}$, respectively. Both binary systems exhibit complete solid solubility. As the temperature of the bond is raised to the melting points of each thin layer $\left(T_{4}\right.$ for $\mathrm{tl}_{\mathrm{A}}$ 


\begin{tabular}{c|c|c|c|c}
\hline substrate & thin & refractory & thin & substrate \\
A & layer & core & layer & B \\
& $\mathrm{A}$ & & $\mathrm{B}$ & \\
\hline
\end{tabular}

Fig. 4 A general PTLP bonding setup

and $T_{3}$ for $\mathrm{tl}_{\mathrm{B}}$ ), both thin layers diffuse into the rc (see $\mathrm{CP} 2{ }_{\mathrm{A}}$ and $\mathrm{CP} 3_{\mathrm{A}}$ as well as $\mathrm{CP} 2_{\mathrm{B}}$ ). Despite the small amount of liquid that initially forms from $t_{B}$ due to its high diffusivity $\left(\mathrm{CP}_{\mathrm{B}}\right)$, the liquid drastically melts back the rc on further heating $\left(\mathrm{CP}_{\mathrm{B}}\right)$ due to the concave shape of the liquidus. This melt-back continues until the assembly is heated to the bonding temperature $\left(T_{5}\right)$ shown in CP5 $\mathrm{a}_{\mathrm{B}}$. On the other hand, the liquid formed from $\mathrm{tl}_{\mathrm{A}}\left(\mathrm{CP} 4_{\mathrm{A}}\right)$ widens slightly to be about the same width as the original thin layer $\left(\mathrm{CP} 5 \mathrm{a}_{\mathrm{A}}\right)$ due to that system's convex liquidus.

At this point, isothermal solidification occurs on both sides of the multi-layer interlayer. It proceeds much faster for $\mathrm{tl}_{\mathrm{B}}$ due to its high partition coefficient and diffusivity. In fact, isothermal solidification is complete for $\mathrm{tl}_{\mathrm{B}}$ $\left(\mathrm{CP} 5 \mathrm{~b}_{\mathrm{B}}\right)$ when the other liquid region has only solidified about halfway $\left(\mathrm{CP} 5 \mathrm{~b}_{\mathrm{A}}\right)$, despite the considerable melt-back of the rc.

The liquid formed from $\mathrm{tl}_{\mathrm{A}}$ eventually solidifies isothermally $\left(\mathrm{CP} 5 \mathrm{c}_{\mathrm{A}}\right)$. On the other side of the bond, the solute peak has been smoothed due to homogenization $\left(\mathrm{CP} 5 \mathrm{c}_{\mathrm{B}}\right)$, and the remelting temperature on that side has increased to $T_{\mathrm{R}, \mathrm{P}}$.

Further homogenization causes the remaining gradient in the $\mathrm{tl}_{\mathrm{B}}$ element to disappear $\left(\mathrm{CP} 5 \mathrm{~d}_{\mathrm{B}}\right)$, thereby raising the

Table 4 A spectrum of materials joined by PTLP bonding

\begin{tabular}{|c|c|c|c|}
\hline \multicolumn{2}{|l|}{ Substrate } & Interlayer $^{\mathrm{a}}$ Combination(s) & Reference(s) \\
\hline \multicolumn{4}{|l|}{ Ceramics } \\
\hline \multicolumn{2}{|l|}{$\mathrm{Al}_{2} \mathrm{O}_{3}$} & $\begin{array}{l}\mathrm{Cr}|\mathrm{Cu}| \mathrm{Ni}|\mathrm{Cu}| \mathrm{Cr}, \mathrm{Cu}|\mathrm{Nb}| \mathrm{Cu}, \mathrm{Cu}|\mathrm{Ni}| \mathrm{Cu}, \mathrm{Cu}|\mathrm{Ni}-\mathrm{Cr}| \mathrm{Cu} \text {, } \\
\mathrm{Cu}|\mathrm{Pt}| \mathrm{Cu}, \mathrm{In}\left|\mathrm{Ag} \mathrm{ABA}^{\mathrm{c}}\right| \mathrm{In}, \mathrm{In}\left|\mathrm{Cusil} \mathrm{ABA}^{\mathrm{c}}\right| \mathrm{In}, \\
\text { In | Incusil } \mathrm{ABA}^{\mathrm{c}}|\mathrm{In}, \mathrm{Ni}| \mathrm{Nb}|\mathrm{Ni}, \mathrm{Ti}| \mathrm{Al} \mid \mathrm{Ti}\end{array}$ & $\begin{array}{l}{[143,188,189,201,207,211-213} \\
215,216,218,220-222,230,232]\end{array}$ \\
\hline \multicolumn{2}{|l|}{ Glass } & $\mathrm{Au}|\mathrm{InBi}| \mathrm{Au}$ & [139] \\
\hline \multicolumn{2}{|l|}{$\mathrm{Si}_{3} \mathrm{~N}_{4}$} & $\begin{array}{l}\mathrm{Al}|\mathrm{Ti}| \mathrm{Al}, \mathrm{Au}|\mathrm{Ni}-\mathrm{Cr}| \mathrm{Au}, \mathrm{Cu}-\mathrm{Au}|\mathrm{Ni}| \mathrm{Cu}-\mathrm{Au}, \mathrm{Co}|\mathrm{Nb}| \mathrm{Co}, \\
\mathrm{Co}|\mathrm{Ta}| \mathrm{Co}, \mathrm{Co}|\mathrm{Ti}| \mathrm{Co}, \mathrm{Co}|\mathrm{V}| \mathrm{Co}, \mathrm{Cu}-\mathrm{Au}-\mathrm{Ti}|\mathrm{Ni}| \mathrm{Cu}-\mathrm{Au}-\mathrm{Ti}, \\
\mathrm{Cu}-\mathrm{Ti}|\mathrm{Pd}| \mathrm{Cu}-\mathrm{Ti}, \mathrm{Ni}|\mathrm{Ti}| \mathrm{Ni}|\mathrm{Ti}| \mathrm{Ni}, \mathrm{Ni}|\mathrm{V}| \mathrm{Ni}, \\
\mathrm{Ti}|\mathrm{Au}| \mathrm{Cu}|\mathrm{Au}| \mathrm{Ni}|\mathrm{Au}| \mathrm{Cu}|\mathrm{Au}| \mathrm{Ti}, \mathrm{Ti}|\mathrm{Cu}| \mathrm{Ti}, \\
\mathrm{Ti}|\mathrm{Cu}| \mathrm{Ni}|\mathrm{Cu}| \mathrm{Ti}, \mathrm{Ti}|\mathrm{Ni}| \mathrm{Ti}, \mathrm{Ti}|\mathrm{Ni}| 304 \mathrm{SS}^{\mathrm{c}}|\mathrm{Ni}| \mathrm{Ti}, \\
\mathrm{Ti}|\mathrm{Ni}| \mathrm{Kovar}^{\mathrm{c}}|\mathrm{Ni}| \mathrm{Ti}, \mathrm{V}|\mathrm{Co}| \mathrm{V}\end{array}$ & $\begin{array}{l}{[117,202,206-208,210-212,214} \\
217,223,224]\end{array}$ \\
\hline \multicolumn{2}{|l|}{$\mathrm{SiC}$} & $\begin{array}{l}\mathrm{C} \text { | } \mathrm{Si}|\mathrm{C}, \mathrm{Cu}-\mathrm{Au}-\mathrm{Ti}| \mathrm{Ni}|\mathrm{Cu}-\mathrm{Au}-\mathrm{Ti}, \mathrm{Ni}-\mathrm{Si}| \mathrm{Mo} \mid \mathrm{Ni}-\mathrm{Si} \text {, } \\
\text { Ti }|\mathrm{Au}| \mathrm{Cu}|\mathrm{Au}| \mathrm{Ni}|\mathrm{Au}| \mathrm{Cu}|\mathrm{Au}| \mathrm{Ti}\end{array}$ & {$[116,210,212,213,227]$} \\
\hline \multicolumn{2}{|l|}{ WC } & $\mathrm{Zn}|\mathrm{Pd}| \mathrm{Zn}$ & [219] \\
\hline \multicolumn{2}{|l|}{$\mathrm{Y}_{2} \mathrm{O}_{3}$-stabilized $\mathrm{ZrO}_{2}$} & $\mathrm{Al}|\mathrm{Ni}| \mathrm{Al}, \mathrm{Ni}|\mathrm{Nb}| \mathrm{Ni}$ & {$[216,231]$} \\
\hline \multicolumn{2}{|c|}{$\mathrm{ZrO}_{2}$-toughened $\mathrm{Al}_{2} \mathrm{O}_{3}$} & $\mathrm{Ni}|\mathrm{Nb}| \mathrm{Ni}$ & [216] \\
\hline \multicolumn{4}{|l|}{ Composites $^{\mathrm{b}}$} \\
\hline \multicolumn{2}{|l|}{$\mathrm{Al} / \mathrm{SiC}$} & $\mathrm{Cu}|\mathrm{Ni}| \mathrm{Cu}$ & {$[144]$} \\
\hline \multicolumn{2}{|l|}{$\mathrm{Si}_{3} \mathrm{~N}_{4} / \mathrm{TiC}$} & Ti | Ni | Ti & [203] \\
\hline \multicolumn{2}{|l|}{$\mathrm{Al} 6061 / \mathrm{Al}_{2} \mathrm{O}_{3}$} & $\mathrm{Cu}|\mathrm{Ni}| \mathrm{Cu}$ & [209] \\
\hline \multicolumn{2}{|l|}{$\mathrm{C} / \mathrm{C}$} & Ti | Ni I Ti & [226] \\
\hline \multicolumn{4}{|l|}{ Metals to ceramics } \\
\hline \multicolumn{2}{|c|}{$\begin{array}{l}\mathrm{FA}-129\left(\mathrm{Fe}_{3} \mathrm{Al} \quad \mathrm{Si}_{3} \mathrm{~N}_{4}\right. \\
\text { alloy, } \mathrm{Fe}-\mathrm{Al}-\mathrm{Cr}- \\
\mathrm{Nb})\end{array}$} & $\mathrm{Cu}-\mathrm{Ti}\left(\mathrm{ABA}^{\mathrm{c}}\right)|\mathrm{Cu}| \mathrm{Cu}-\mathrm{Ti}\left(\mathrm{ABA}^{\mathrm{c}}\right), \mathrm{Cu}-\mathrm{Ti}|\mathrm{Cu}| \mathrm{Ni} \mid \mathrm{Al}$ & {$[202,204,205]$} \\
\hline $\operatorname{Kovar}^{\mathrm{c}}$ & $\mathrm{Al}_{2} \mathrm{O}_{3}$ & $\mathrm{Ni}|\mathrm{Ti}| \mathrm{Ni}$ & [200] \\
\hline $\mathrm{Ni}$ & $\mathrm{Si}_{3} \mathrm{~N}_{4}$ & $\mathrm{Ti}|\mathrm{Ni}| \mathrm{Ti}$ & [225] \\
\hline $\mathrm{Si}$ & $\mathrm{Al}_{2} \mathrm{O}_{3}$ & $\mathrm{Ti}|\mathrm{Cu}| \mathrm{Sn}|\mathrm{Au}| \mathrm{Cu}$ & [229] \\
\hline
\end{tabular}

${ }^{a}$ Interlayer material compositions are notated as either (1) $\mathrm{X}-\mathrm{Y}$ where $\mathrm{X}$ is the base element and $\mathrm{Y}$ is the minor alloying element or (2) one of the following braze alloy designations, in weight percent: Cusil (Ag-28Cu), Incusil (Ag-27.3Cu-12.5In-1.3Ti), and Ticusil (Ag-26.7Cu-4.5Ti)

${ }^{\mathrm{b}}$ Composites are notated as $\mathrm{X} / \mathrm{Y}$ where $\mathrm{X}$ is the matrix material and $\mathrm{Y}$ is the composite fiber material

c $A B A$ active brazing alloy, Kovar Fe-Ni-Co alloy, SS stainless steel 
Fig. 5 A schematic binary system with complete solid solubility and associated concentration profiles for one half of the PTLP bonding process (thin layer $\mathrm{A}\left[\mathrm{tl}_{\mathrm{A}}\right]$ and refractory core). These profiles illustrate the thin layer A element's concentration during the PTLP bonding process, starting with the initial condition $\left(\mathrm{CP} 1_{\mathrm{A}}\right)$ and ending with the completely homogenized bond $\left(\mathrm{CP}_{\mathrm{f}} \mathrm{A}\right)$

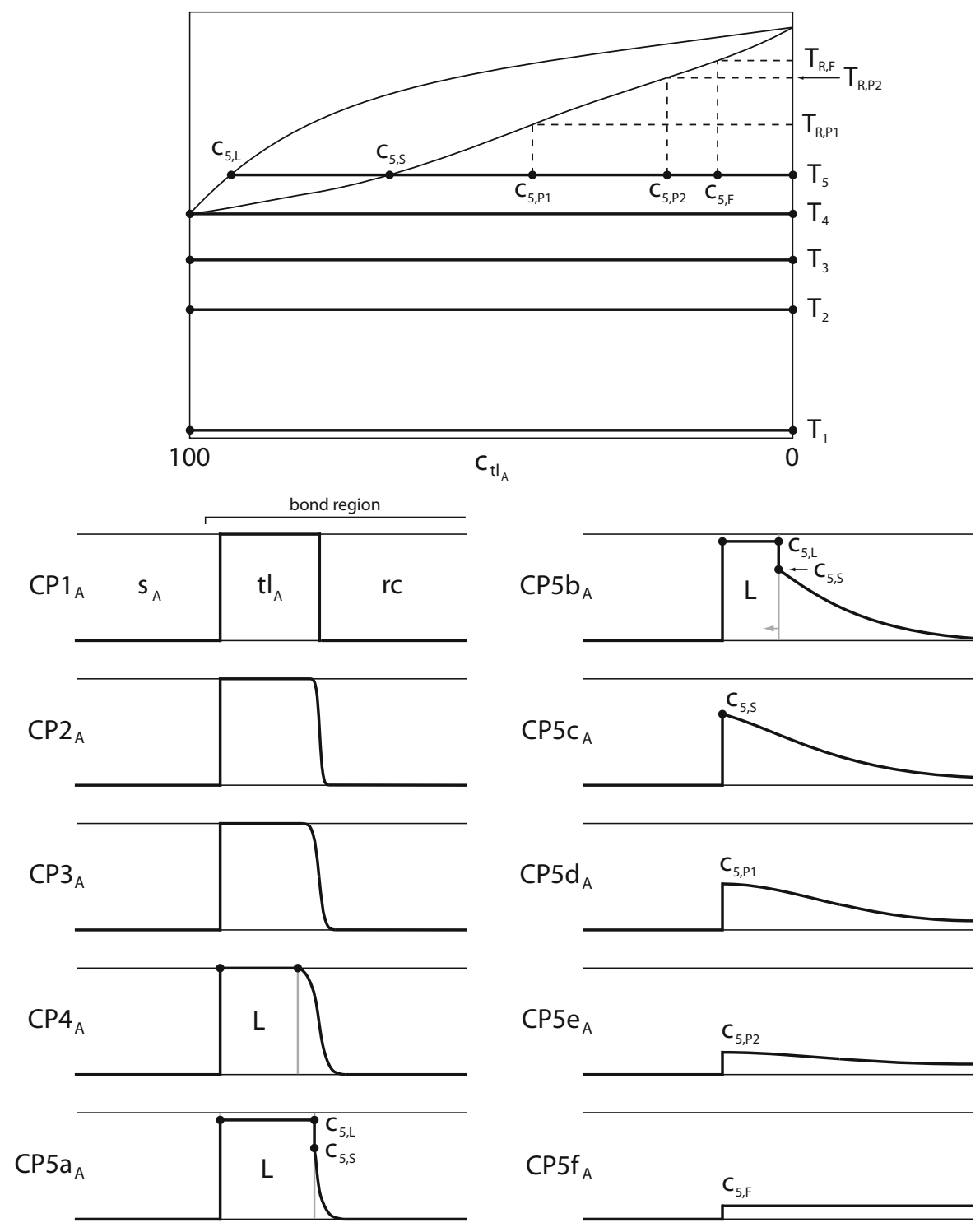

remelting temperature of the bond next to substrate $\mathrm{B}$ to its final value, $T_{\mathrm{R}, \mathrm{F}}$. A similar melting temperature increase (to $\left.T_{\mathrm{R}, \mathrm{P} 1}\right)$ simultaneously occurs on the other side of the bond due to smoothing of its solute peak $\left(\mathrm{CP} 5 \mathrm{~d}_{\mathrm{A}}\right)$.

Prolonging the homogenization process continues to raise the remelting temperature of the left side of the bond. However, once its remelting temperature has reached $T_{\mathrm{R}, \mathrm{P} 2}$ (CP5 $\mathrm{e}_{\mathrm{A}}$ ), which is higher than $T_{\mathrm{R}, \mathrm{F}}$ for the right side of the bond, further homogenization will have little effect on raising the bond's remelting temperature. From an optimization standpoint, homogenization should be stopped at this time. However, real-world considerations usually determine the homogenization time, which can be less than-or greater than-the optimized time due to various factors, such as cost, microstructural considerations, or resulting bond strength.
The time frame of PTLP bonding is very similar to that of TLP bonding. Isothermal solidification and homogenization times for TLP bonding depend on high-diffusivity elements diffusing into "infinite" substrate materials. In PTLP bonding, the elements tend to have lower diffusivities, but the maximum diffusion path is on the order of $100 \mu \mathrm{m}$, resulting in similar bonding times.

\section{Advantages and disadvantages of PTLP bonding}

The "self-contained" [215] nature of the PTLP bonding multi-layer interlayer provides benefits and impediments. Specific advantages include the following:

- the dual nature of the multi-layer interlayer combines some beneficial properties of brazing and diffusion 
Fig. 6 A schematic binary system with complete solid solubility and associated concentration profiles for one half of the PTLP bonding process (refractory core and thin layer $\left.\mathrm{B}\left[\mathrm{tl}_{\mathrm{B}}\right]\right)$. These profiles illustrate the thin layer B element's concentration during the PTLP bonding process, starting with the initial condition $\left(\mathrm{CP} 1_{\mathrm{B}}\right)$ and ending with the completely homogenized bond (CP5 $\left.\mathrm{f}_{\mathrm{B}}\right)$

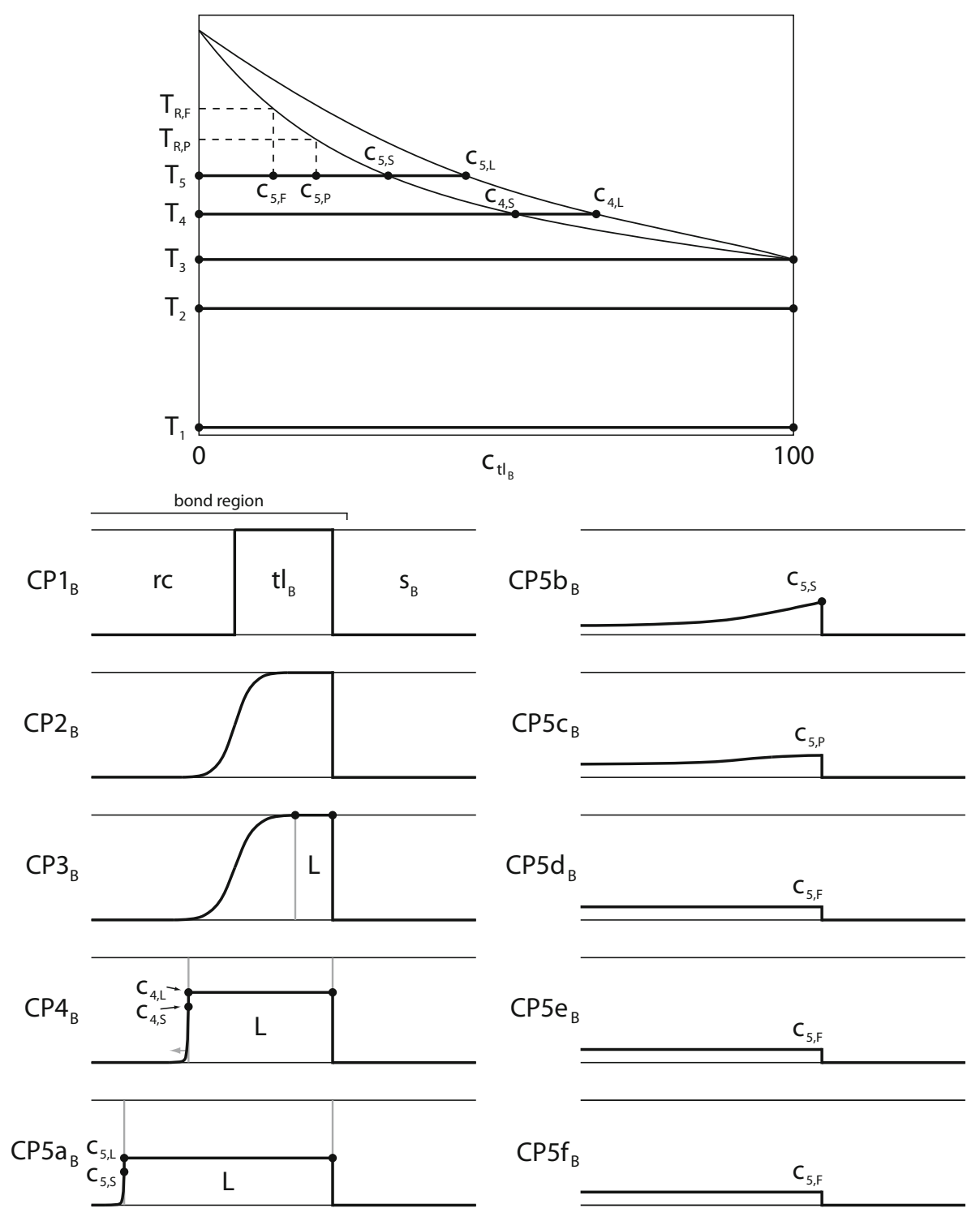

bonding [117, 188, 204, 206, 208, 215] and provides some flexibility in joint design

- lower bonding temperatures can mitigate thermally induced stresses [188, 214] and limit or avoid deleterious intermetallic reactions [188, 207]

- because diffusion occurs on a smaller scale (on the order of $100 \mu \mathrm{m}$ ), bonding using slow-diffusing elements occurs in a reasonable amount of time.

Major disadvantages are:

- the liquid interlayer must wet the ceramic [117, 143, 215]

- matching the thermal expansion coefficients of the ceramic substrates and metallic interlayer elements is sometimes necessary to prevent thermally induced stresses and cracking [117, 143, 188, 196, 203, 215]
- intermetallic formation is necessary, but a thick reaction layer tends to be brittle and can degrade joint strength [143, 200, 202, 203, 210, 215].

However, most disadvantages of PTLP bonding can be overcome by proper design. In the end, the limiting factor is wettability on the specific ceramic material.

\section{Applications of PTLP bonding}

PTLP bonding has been used to successfully join some ceramic and composite materials. Table 4 presents a spectrum of PTLP bonds as of now, including bonds of dissimilar materials. The interlayer combination of the general PTLP bond setup shown in Fig. 4 would be notated $\mathrm{tl}_{\mathrm{A}}|\mathrm{rc}| \mathrm{tl}_{\mathrm{B}}$. 


\section{Summary}

TLP bonding is a relatively new bonding process that results in a bond with a higher melting temperature than that used to join the materials. Specific details of this process, including experimental details, process kinetics, and optimal bonding temperature, have been outlined in this article. Also, the broad range of materials that have been joined by TLP bonding was presented.

PTLP bonding, a more recent variant of TLP bonding used to bond hard-to-join materials, was also outlined. PTLP bonding has been successful in joining a smaller range of materials, most notably, ceramics.

Both TLP and PTLP bonding are specialized joining processes that require more resources to implement compared to typical bonding processes. However, in some cases these bonding processes are the best-or only-way to join materials for specialized applications.

Acknowledgements This study was funded by the Office of Naval Research under grant number N00014-07-1-0872, Dr. William Mullins, Program Officer.

\section{References}

1. Paulonis D, Duvall D, Owczarski W (1971) US Pat 3,678,570 1 Apr 2010

2. Zhang L, Hou J, Zhang S (2007) China Weld 16(1):63

3. Lee BK, Song WY, Kim DU, Woo IS, Kang CY (2007) Met Mat Int 13(1):59

4. Abdelfatah M, Ojo OA (2009) Mat Sci Technol 25(1):61

5. Ojo OA, Richards NL, Charturvedi MC (2004) Sci Technol Weld Join 9(3):209

6. Dinkel MK, Heinz P, Pyczak F, Volek A, Ott M, Affeldt E, Vossberg A, Göken M, Singer RF (2008) In: Proceedings of the international symposium on superalloys. TMS, Warrendale, p 211

7. Gale WF, Butts DA (2004) Sci Technol Weld Join 9(4):283

8. Kuntz ML (2006) Quantifying isothermal solidification kinetics during transient liquid phase bonding using differential scanning calorimetry. $\mathrm{Ph}$. D dissertation, University of Waterloo

9. Schnell A, Stankowski A, deMarcos E (2006) In: Proceedings of GT2006, ASME Turbo Expo 2006: power for land, sea, air, Barcelona, 8-11 May 2006

10. Peaslee RL (1976) Weld J 55(8):695

11. Wu X, Chandel RS, Li H (2001) J Mat Sci 36:1539. doi: 10.1023/A:1017513200502

12. Gale WF (1999) J Mat 51(2):49

13. Gale WF (2003) Mat Sci Forum 426-432:1891

14. Duvall DS, Owczarski WA, Paulonis DF (1974) Weld J 53(4):203

15. Tian J, Kim T, Lu TJ, Hodson HP, Queheillalt DT, Sypeck DJ, Wadley HNG (2004) Int J Heat Mass Trans 47(14/16):3171

16. Laux B, Piegert S, Rösler J (2009) Metall Mat Trans A 40(1):138

17. Metzger GE (1976). In: Technical report AFML-TR-75-210, Air Force Materials Lab, Wright-Patterson Air Force Base, Ohio, 1976

18. MacDonald WD, Eagar TW (1998) Metal Mat Trans $29 \mathrm{~A}(1): 315$
19. MacDonald WD, Eagar TW (1992) Ann Rev Mat Sci 22:23

20. Xu Q, Chaturvedi MC, Richards NL, Goel N (1997) In: ISSI: Structural intermetallics 1997, proceedings of the 2nd international symposium on structural intermetallics, champion, p 323, 21-25 Sept 1997

21. Shirzadi AA (1998) Weld World 41(5):435

22. Suzumura A, Xing Y (1996) Jpn Inst Met Mat Trans 37(5):1109

23. AlHazaa A, Khan TI, Haq I (2010) Mat Charact 61(3):312

24. Ekrami A, Khan TI, Malik H (2003) Mat Sci Technol 19:132

25. Padron T, Khan TI, Kabir MJ (2004) Mat Sci Eng A 385(1-2):220

26. Nishimoto K, Saida K, Kim D, Asai S, Furukawa Y, Nakao S (1998) Weld World 41(2):121

27. Johnsen MR (2007) Weld J 86(3):76

28. Wang J, Li Y, Huang W (2009) Mat Sci 45(1):125

29. Duan H, Bohm KH, Ventzke V, Koçak M (2005) Trans Nonferrous Met Soc China 15(2):375

30. Yang CF, Chiu LH, Lee SC, Sun JY (1998) Proc Natl Sci Counc Repub China A Phys Sci Eng 22(1):132

31. Brochu M, Wanjara P (2007) Int J Refract Met Hard Mat 25(1):67

32. Kejanli H, Taskin M, Kolukisa S, Topuz P (2010) Int J Adv Manuf Technol 44(7/8):695

33. Maity J, Pal TK, Maiti R (2009) J Mat Process Technol 209:3568

34. Freedman AH (1971) Weld J 50:343s

35. Krishnardula VG, Sofyan NI, Gale WF, Fergus JW (2006) Metall Mat Trans A 37A(2):497

36. Li H, Li ZX (2008) J Sandw Struct Mat 10(3):247

37. Li H, Li ZX (2008) J Mat Eng Perform 17(6):849

38. Wikstrom NP, Idowu OA, Ojo OA, Chaturvedi MC (2006) In: Proceedings of the 3rd international brazing and soldering conference, Crowne Plaza Riverwalk Hotel, San Antonio, 2006

39. Zhai Y, North TH (1997) J Mat Sci 32(21):5571. doi: 10.1023/A: 1018624507922

40. Guedes A, Viana F, Pinto AMP, Vieira MF (2008) Mat Sci Forum 587-588:425

41. Huang X, Richards NL (2004) Weld J 83(3):73s

42. Zhang G, Zhang J, Pei Y, Li S, Chai D (2008) Mat Sci Eng A 488(1-2): 146

43. Tuah-Poku I, Dollar M, Massalski TB (1988) Metall Trans A 19A(3):675

44. Kuntz ML, Zhou Y, Corbin SF (2006) Metall Mat Trans A $37 \mathrm{~A}(8): 2493$

45. Ojo OA, Abdelfatah MM (2008) Mat Sci Technol 24(6):739

46. Dolgov YS, Sidokhin AF, Sidokhin YF (1968) Weld Prod 15(12):24

47. Yuan X, Kim MB, Kang CY (2009) Mat Charact 60(11):1289

48. Askew JR, Wilde JF, Khan TI (1998) Mat Sci Technol 14(9-10):920

49. Elrefaey A, Tillmann W (2009) Adv Eng Mat 11(7):556

50. Wikstrom NP, Egbewande AT, Ojo OA (2008) J Alloys Compd 460(1/2):379

51. Duan H, Koçak M, Bohm KH, Ventzke V (2004) Sci Technol Weld Join 9(6):513

52. Dezellus O, Andrieux J, Bosselet F, Sacerdote-Peronnet M, Baffie T, Hodaj F, Eustathopoulos N, Viala JC (2008) Mat Sci Eng A 495(1/2):254

53. Ghoneim A, Ojo OA (2010) Intermet 18(4):582

54. Zhai Y, North TH, Serrato-Rodrigues J (1997) J Mat Sci 32(6):1393. doi:10.1023/A:1018624507922

55. Abdo ZAM, Guan Y, Gale WF (1999) In: High-temperature ordered intermetallic alloys VIII, MRS Fall Meeting, Boston, 1998

56. Guan Y, Gale WF (1999) Mat Sci Technol 15(2):207 
57. Gale WF, Guan Y (1999). In: 5th International conference: Trends in Welding Research; Pine Mountain, 1998

58. Gale WF, Guan Y, Orel SV (1998) Int J Mat Prod Technol 13(1-2): 1

59. Nakahashi M, Suenaga S, Shirokane M, Takeda H (1992) Jpn Inst Met Mat Trans 33:60

60. Chen SJ, Tang HJ, Jing XT (2009) Mat Sci Eng A 499(1-2):114

61. Khan TI, Kabir MJ, Bulpett R (2004) Mat Sci Eng A 372(1-2):290

62. Khan TI, Wallach ER (1996) Mat Sci Technol 12(7):603

63. Khan TI, Wallach ER (1996) J Mat Sci 31(11):2937. doi: 10.1007/BF00356005

64. Wei S (1996) Rare Met 15(1):16

65. Nishimoto K, Saida K, Shinohara Y (2003) Sci Technol Weld Join 8(1):29

66. Mosallaee M, Ekrami A, Ohsasa K, Matsuura K (2008) Mat Sci Technol 24(4):449

67. Zhang G, Zhang J, Pei Y (2006) China Weld 15(1):16

68. Pouranvari M, Ekrami A, Kokabi AH (2008) J Alloys Compds 461(1/2):641

69. Orel SV, Parous LC, Gale WF (1995) Weld J 74(9):319s

70. Kim DU, Nishimoto K (2003) Mat Sci Technol 19(4):456

71. Nishimoto K, Saida K, Kim D, Nakao Y (1995) Iron Steel Inst Jpn Int 35(10): 1298

72. Khan TI, Roy BN (2004) J Mat Sci 39(2):741. doi: 10.1023/B:JMSC.0000011546.44307.42

73. Fukumoto S, Imamura K, Hirose A, Kobayashi KF (1995) Iron Steel Inst Jpn Int 35(10):1307

74. Di Luozzo N, Fontana M, Arcondo B (2007) J Mat Sci 42(11):4044. doi:10.1007/s10853-006-0190-9

75. Epelbaum C, Fontana M, Audebert F, Arcondo B (2005) J Mat Sci 40(18):4867. doi:10.1007/s10853-005-3883-6

76. Khan TI, Orhan N, Eroglu M (2002) Mat Sci Technol 18(4):396

77. Chen H, Gong JM, Tu ST (2009) Sci Technol Weld Join 14(1):32

78. Idowu OA, Richards NL, Chaturvedi MC (2005) Mat Sci Eng A 397:98

79. Pouranvari M, Ekrami A, Kokabi AH (2009) J Alloys Compds 469(1-2):270

80. Mosallaee M, Ekrami A, Ohsasa K, Matsuura K (2008) Metall Mat Trans A 39A(10):2389

81. Gale WF, Wallach ER (1991) Metall Trans A 22A(10):2451

82. Pouranvari M, Ekrami A, Kokabi AH (2008) Mat Sci Eng A 490(1/2):229

83. Zou GS, Xie EH, Bai HL, Wu AP, Wang Q, Ren JL (2009) Mat Sci Eng A 499(1-2):101

84. Gale WF, Orel SV (1996) J Mat Sci 31(2):345. doi: 10.1007/BF01139150

85. Tseng MW, Williams DB, Soni KK, Levi-Setti R (1999) J Mat Sci 34:5187. doi:10.1023/A:1004707812417

86. Ojo OA, Richards NL, Chaturvedi MC (2004) Sci Technol Weld Join 9(6):532

87. Chaturvedi MC, Ojo OA, Richards NL (2004) Adv Technol Mat Mat Process J 6(2):206

88. Ikawa H, Nakao Y, Isai T (1979) Trans Jpn Weld Soc 10(1):25

89. Lu CD, Chang LS, Lu YF, Lu FH (2009) Ceram Int 35(7):2699

90. Maity J, Pal TK, Maiti R (2009) Mat Sci Technol 25(12):1489

91. Wadley H, Dharmasena K, Chen Y, Dudt P, Knight D, Charette R, Kiddy K (2008) Int J Impact Eng 35(9):1102

92. Gale WF, Wen X (2001) Mat Sci Technol 17(4):459

93. Huang JH, Wan Y, Zhao HT, Cheng DH, Zhang H (2007) Mat Sci Technol 23(1):87

94. Gale WF, Butts DA, Di Ruscio M, Zhou T (2002) Metall Mat Trans A 33A(10):3205

95. Butts DA, Gale WF (2008) Mat Sci Technol 24(12):1492

96. Zhou T, Gale WF, Butts D, Di Ruscio M (2003) In: Materials solutions '02, Columbus, 2003
97. Sukhachev AP, Lashko SV (1971) Weld Prod 18(6):86

98. Huang J, Wan Y, Zhang H, Zhao X (2007) J Mat Sci 42(23):9746. doi:10.1007/s10853-007-2016-9

99. Zhuang WD, Eagar TW (1997) Weld J 76(4):157s

100. Gale WF, Xu Y, Wen X, Abdo ZAM (1999) Metall Mat Trans A 30(10):2723

101. Gale WF, Guan Y (1999) Mat Sci Technol 15(4):464

102. Zhang W, Ruythooren W (2008) J Electron Mat 37(8):1095

103. Koyama S, Takahashi M, Ikeuchi K (2007) Mat Sci Forum 539-543:3503

104. Arafin MA, Medraj M, Turner DP, Bocher P (2007) Mat Sci Eng A $447(1-2): 125$

105. Li Z, Zhou Y, North TH (1995) J Mat Sci 30(4):1075. doi: 10.1007/BF01178448

106. Lee JS, Bang WH, Jung JP, Oh KH (2005) Mat Sci Forum 475-479:1869

107. Niemann JT, Wille GW (1978) Weld J 57(10):285s

108. Saha RK, Khan TI (2009) Mat Charact 60(9):1001

109. Kay WD (1993) ASM Handbook: welding, brazing, soldering, vol. 6. ASM International, Metals Park

110. Sangha SPS, Jacobson DM, Peacock AT (1998) Weld J 77(10):432s

111. Rezchik NV, Kheifets RG (1988) Weld Int 2(2):118

112. Chernitsyn AI, Kufaikin AA, Rastorguev LN, Lozeev GE (1975) Weld Prod 22(7):36

113. Moore TJ, Kalinowski JM (1993) In: High-temperature ordered intermetallic alloys V, Boston, 1992

114. Bosco NS, Zok FW (2004) Acta Mater 52:2965

115. Gale WF, Orel SV (1996) Metall Mat Trans A 27A(7):1925

116. Liu GW, Valenza F, Muolo ML (2010) J Mat Sci 45:4299. doi: 10.1007/s10853-010-4337-3

117. Tillmann W, Lugscheider E (1996) Int J Join Mat 8(2):56

118. Lo PL, Chang LS, Lu YF (2009) Ceram Int 35(8):3091

119. Li W, Jin T, Sun X, Guo Y, Guan H, Hu Z (2002) J Mat Sci Technol 18:54

120. Elthalabawy W, Khan T (2010) Mat Charact 61:703

121. Sun DQ, Liu WH, Gu XY (2004) Mat Sci Technol 20(12):1595

122. Gu XY, Sun DQ, Liu L (2008) Mat Sci Eng A 487(1-2):86

123. Gu XY, Sun DQ, Liu L, Duan ZZ (2009) J Alloys Compds 476(1-2):492

124. Le Blanc A, Mevrel R (1990) In: High temperature materials for power engineering 1990, II. Kluwer Academic, Liege

125. Saha RK, Khan TI (2007) J Mat Sci 42(22):9187. doi: 10.1007/s10853-007-1922-1

126. Khan TI, Wallach ER (1995) J Mat Sci 30(20):5151. doi: 10.1007/BF00356063

127. Lee YS, Seo KW, Lee CH, Lim CH, Lee CH (2006) Mat Sci Forum 510-511:390

128. Liu JD, Jin T, Zhao NR, Wang ZH, Sun XF, Guan HR, Hu ZQ (2010) Sci Technol Weld Join 15(3): 194

129. Shirzadi AA, Saindrenan G (2003) Sci Technol Weld Join $8(2): 149$

130. Krishnardula VG, Sofyan NI, Fergus JW, Gale WF (2006) In: Trends in welding research, Proceedings of the 7th International Conference, Cancun

131. Noh S, Kasada R, Oono N, Iwata N, Kimura A (2010) Fusion Eng Des 85:1033

132. Zhou S, Li X, Xiong W, Zhou Y (2009) J Wuhan Univ Technol Mat Sci Ed 24(3):432

133. Rhee BH, Kim DU (2002) Met Mat 8(5):427

134. Lashko NF, Lashko SV, Grishin VL (1968) Weld Prod 15(3):5

135. Egbewande AT, Chukwukaeme C, Ojo OA (2008) Mat Charact 59(8): 1051

136. Aluru R, Sofyan NI, Fergus JW, Gale WF (2006) In: Trends in welding research, Proceedings of the 7th International Conference, Auburn, p 879 
137. Bach FW, Deisser TA, Hollaender U, Moehwald K, Nicolaus M (2007) Weld J 86(12):373s

138. Ramirez JE, Liu S (1992) Weld J 71(10):365s

139. Bobzin K, Lugscheider E, Ernst F, Nickel R, Bagcivan N, Parkot D, Schlegel A, Ferrara S, Kashko T, Leick N (2008) Microsyst Technol 14(12):1887

140. Kwon YS, Kim JS, Moon JS, Suk MJ (2000) J Mat Sci 35(8):1917. doi:10.1023/A:1004762318057

141. Saha RK, Khan TI (2006) J Mat Eng Perform 15(6):722

142. Zhou Y, North TH (1993) Model Simul Mat Sci Eng 1(4):505

143. Ksiazek M, Sobczak N, Mikulowski B, Radziwill W, Winiarski B, Wojcik M (2005) J Mat Sci 40:2513. doi:10.1007/s10853005-1984-X

144. Chen R, Zuo D, Wang M (2006) J Mat Sci Technol 22(3):291

145. Sun D, Liu W, Wu J, Jia S, Qiu X (2002) China Weld 11(1):9

146. Sun D, Liu W, Jia S, Qiu X (2004) Trans Nonferrous Met Soc China 14(1): 105

147. Jalilian F, Jahazi M, Drew RAL (2006) Mat Sci Eng A 423(1-2):269

148. Natsume Y, Ohsasa K, Tayu Y, Momono T, Narita T (2003) Iron Steel Inst Int 43(12): 1976

149. Aluru R, Gale WF, Chitti SV, Sofyan N, Love RD, Fergus JW (2008) Mat Sci Technol 24(5):517

150. Sun DQ, Gu XY, Liu WH (2005) Mat Sci Eng A 391(1-2):29

151. Bosco NS, Zok FW (2005) Acta Mater 53(7):2019

152. Johnson RW, Wang C, Liu Y, Scofield JD (2007) IEEE Trans Electron Packag Manuf 30(3):182

153. Rhee B, Roh S, Kim D (2003) Mat Trans 44(5):1014

154. Schwartz MM (1978) Weld J 57:35

155. Grishin VL, Lashko SV (1986) Weld Prod 33:23

156. Jalilian $F$ (2006) The influence of process parameters on TLP bonding of inconel 617 superalloy. Ph. D dissertation, McGill University

157. Campbell CE, Boettinger WJ (2000) Metall Mat Trans A $31 \mathrm{~A}(11): 2835$

158. Heinz P, Volek A, Singer RF, Dinkel M, Pyczak F, Göken M, Ott M, Affeldt E, Vossberg A (2008) Diffus Defect Data A 273-276:294

159. Abdelfatah MM, Ojo OA (2009) Metall Mat Trans A 40(2):377

160. Peaslee RL (2002) Weld J 81(2):170

161. Li JF, Agyakwa PA, Johnson CM (2010) J Mat Sci 45(9):2340. doi:10.1007/s10853-009-4199-8

162. Abdelfattah M (2008) An experimental and theoretical study of transient liquid phase bonding of nickel based materials. Ph. D dissertation, University of Manitoba

163. Cain SR, Wilcox JR, Venkatraman R (1997) Acta Mater 45(2):701

164. Assadi H, Shirzadi AA, Wallach ER (2001) Acta Mater 49(1):31

165. Tillmann W, Osmanda AM, Wojarski L (2009) Q J Jpn Weld Soc 27(2): $179 \mathrm{~s}$

166. Natsume Y, Ohsasa K, Narita T (2003) Mat Trans 44(5):819

167. Shinmura T, Ohsasa K, Narita T (2001) Mat Trans 42(2):292

168. Ohsasa K, Shinmura T, Narita T (1999) J Phase Equilib 20(3):199

169. Yuan X, Kim MB, Kang CY (2011) Metal Mat Trans A 42(5): 1310

170. Kato H, Kageyama K (1998) Mat Sci Technol 14(7):712

171. Iseki T, Yamashita K, Suzuki H (1981) J Am Ceram Soc 64(1):C-13

172. Atabaki M (2010) J Nucl Mat 406:330

173. Zhou Y, Gale WF, North TH (1995) Int Mater Rev 40(5):181

174. Sinclair CW (1999) J Phase Equilib 20(4):361

175. Zhou Y (2001) J Mat Sci Lett 20:841

176. Illingworth TC, Golosnoy IO, Clyne TW (2007) Mat Sci Eng A 445-446:493

177. Okamoto H (1997) J Phase Equilib 18(5):491
178. Wikstrom NP (2006) The effect of process parameters on microstructure of transient liquid phase bonded superalloys inconel 738 and waspaloy. Ph. D dissertation, University of Manitoba

179. Zhou Y, North TH (1994) Zeitschrift fur Metallkunde 85(11):775

180. Hong SM (2009) Transient-liquid-phase (TLP) bonding of $\mathrm{Al}_{2} \mathrm{O}_{3}$ using Nb-based multilayer interlayers. $\mathrm{Ph}$. D dissertation, University of Calif, Berkeley

181. Saha RK (2008) Transient liquid phase diffusion bonding of an oxide dispersion strengthened nickel superalloy. Ph. D dissertation, University of Calgary

182. Illingworth TC, Golosnoy IO, Gergely V, Clyne TW (2005) J Mat Sci 40(9-10):2505. doi:10.1007/s10853-005-1983-y

183. Jen TC, Jiao Y (2001) Num Heat Trans A 39(2):123

184. Sinclair CW, Purdy GR, Morral JE (2000) Metall Mat Trans A 31A(4):1187

185. Loehman R (1981) In: Pask J, Evans A (eds) Proceedings of the 17th University Conference on Ceramics held University of California, Berkeley, p 701

186. Shirzadi AA, Wallach ER (1999) Acta Mater 47(13):3551

187. Lugscheider E, Ferrara S (2004) Adv Eng Mat 6(3):160

188. Shalz ML, Dalgleish BJ, Tomsia AP, Glaeser AM (1993) J Mat Sci 28:1673. doi:10.1007/BF00363367

189. Shalz ML, Dalgleish BJ, Tomsia AP, Glaeser AM (1994) J Mat Sci 29(12):3200. doi:10.1007/BF00356663

190. Nicholas M (1998) Joining processes. Kluwer Academic, Boston, $\mathrm{p} 95$

191. Peaslee RL (1999) Weld J 78(3):237

192. Agarwal R, Zhang W, Limaye P, Ruythooren W (2009) In: Proceedings-electronic components and technology conference, San Diego

193. Wilcoxon RK, Boone AP, Wooldridge JR (2010) US Pat 7,830,0219 Nov 2010

194. Jabbareh MA, Assadi H (2009) Scr Mater 60(9):780

195. Zhou T, Gale WF (2003) Mat Sci Technol 19(8):1084

196. Kim JJ, Park JW, Eagar TW (2003) Mat Sci Eng A 344:240

197. Fergus JW, Salazar VL, Long CJ, Harris NL, Zhou T, Gale WF (2005) J Mater Sci 40(23):6139. doi:10.1007/s10853-005-3166-2

198. Lugscheider E, Ferrara S, Janssen H, Reimann A, Wildpanner B (2004) Microsyst Technol 10:233

199. Chang LS, Huang CF (2004) Ceram Int 30:2121

200. Zhang Y, Feng D, He Z, Chen X (2006) J Iron Steel Res Int 13(2): 1

201. Locatelli MR, Nakashima K, Dalgleish BJ, Tomsia AP, Glaeser AM (1994) In: Advances in ceramic-matrix composites II; proceedings of the symposium, ACS 96th Annual Meeting, Indianapolis, 25-27 Apr 1994

202. Brochu M, Pugh MD, Drew RAL (2002) In: Proceedings from joining of advanced and specialty materials, 5-8 November 2001, Indianapolis, ASM International, 2002

203. Chen Z, Cao MS, Zhao QZ, Zou JS (2004) Mat Sci Eng A 380:394

204. Brochu M, Pugh MD, Drew RAL (2004) Int J Refract Met Hard Mat 22:95

205. Brochu M, Drew RAL, Pugh MD (2002). In: Metal/Ceramic Interactions: as held at the 41st annual conference of metallurgists of CIM (COM 2002), Montreal, 11-14 Aug 2002

206. Peteves SD, Paulasto M, Ceccone G, Stamos V (1998) Acta Mater 46(7):2407

207. Ceccone G, Nicholas MG, Peteves SD, Tomsia AP, Dalgleish BJ, Glaeser AM (1996) Acta Mater 44(2):657

208. Zou GS, Wu AP, Ren JL, Yang J, Zhao WQ (2004) Trans Nonferrous Met Soc China 14(1):93

209. Yan J, Xu Z, We G, Yang S (2005) J Mat Sci 40(19):5307. doi: $10.1007 / \mathrm{s} 10853-005-4394-1$ 
210. Dalgleish BJ, Tomsia AP, Glaeser AM (1994) In: Advances in ceramic-matrix composites II; Proceedings of the symposium, ACS 96th Annual Meeting, Indianapolis, 25-27 Apr 1994

211. Dalgleish BJ, Tomsia AP, Nakashima K, Locatelli MR, Glaeser AM (1994) Scr Metall Mater 31(8): 1043

212. Locatelli MR, Dalgleish BJ, Nakashima K, Tomsia AP, Glaeser AM (1997) Ceram Int 23(4):313

213. Locatelli MR, Tomsia AP, Nakashima K, Dalgleish BJ, Glaeser AM (1995) Key Eng Mater 111-112:157

214. Tillmann W, Lugscheider E, Buschke I (1996). In: Processing and fabrication of advanced materials V, Cincinnati, 6-10 Oct 1996

215. Shalz ML, Dalgleish BJ, Tomsia AP, Cannon RM, Glaeser AM (1994) J Mat Sci 29:3678. doi:10.1007/BF00357335

216. Hong SM, Bartlow CC, Reynolds TB, McKeown JT, Glaeser AM (2008) Adv Mat 20(24):4799

217. Ceccone G, Paulasto M, Nicholas MG, Peteves SD, Glaeser AM (1995) In: 4th European ceramic society Conference vol 9 coatings, Riccione, 1995

218. Locatelli MR, Dalgliesh BJ, Tomsia AP, Glaeser AM, Mastumoto H, Nakashima K (1995) In: 4th European ceramic society conference vol. 9 coatings, Riccione, 1995

219. Cook III GO (2011) Joining polycrystalline cubic boron nitride and tungsten carbide by partial transient liquid phase bonding. $\mathrm{Ph}$. D dissertation, Brigham Young University

220. Nakashima K, Makino T, Mori K, Glaeser AM (1998) J Mater Synth Process 6(4):271
221. Matsumoto H, Locatelli MR, Nakashima K, Glaeser AM, Mori K (1995) Mater Trans JIM 36(4):555

222. Hong SM, Reynolds TB, Bartlow CC, Glaeser AM (2010) Int J Mat Res 101(1):133

223. Iino Y (1991) J Mater Sci Lett 10(2):104

224. Zheng C, Lou H, Fei Z, Li Z (1997) J Mat Sci Lett 16(24):2026

225. Ino Y, Usami H, Oshimoda M, Saito T (1992). In: The first Pacific rim international conference on advanced materials and processing (PRICM-1): proceedings of a meeting held in Hangzhou, 23-27 June 1992

226. Xiong JT, Li JL, Zhang FS, Wang ZP (2007) Key Eng Mat 336-338:1260

227. Loehman RE (1999) Key Eng Mat 161-163:657

228. Naidich YV, Zhuravlev VS, Gab II, Kostyuk BD, Krasovskyy VP, Taranets NY (2006) In: Brazing and soldering: proceedings of the 3rd international brazing and soldering conference, Crowne Plaza Riverwalk Hotel, San Antonio

229. Liang MW, Hsieh TE, Chang SY, Chuang TH (2003) J Electron Mat 32(9):952

230. Sugar J, McKeown J, Akashi T, Hong S, Nakashima K, Glaeser AM (2006) J Eur Ceram Soc 26(4-5):363

231. Akashi T, Nukui T, Kiyono H (2009) J Ceram Soc Jpn 117(9):983

232. Hong SM, Glaeser AM (2006). In: Proceedings of the 3rd international brazing and soldering conference, Crowne Plaza Riverwalk Hotel, San Antonio, 24-26 Apr 2006

233. Benko E, Bielanska E, Pereverteilo VM, Loginova OB (1997) Diam Relat Mat 6:931 